\title{
The Significance of Money for the Cults and Sanctuaries of Demeter and Kore: The Shaping of the Cults by Commercial Transactions
}

\author{
Aynur-Michèle-Sara Karatas
}

\section{(2) OpenEdition}

Journals

Electronic version

URL: http://journals.openedition.org/mythos/297

DOI: $10.4000 /$ mythos. 297

ISSN: 2037-7746

Publisher

Salvatore Sciascia Editore

\section{Printed version}

Date of publication: 1 December 2018

Number of pages: 47-88

ISBN: 978-88-8241-501-3

ISSN: 1972-2516

\section{Electronic reference}

Aynur-Michèle-Sara Karatas, "The Significance of Money for the Cults and Sanctuaries of Demeter and Kore: The Shaping of the Cults by Commercial Transactions ", Mythos [Online], 12 | 2018, Online since 24 September 2019, connection on 10 December 2020. URL : http://journals.openedition.org/ mythos/297; DOI : https://doi.org/10.4000/mythos.297 


\section{The Significance of Money for the Cults and Sanctuaries of Demeter and Kore: The Shaping of the Cults by Commercial Transactions}

\section{A.M. Sara Karatas}

\begin{abstract}
The monetarization of the markets accelerated in the $5^{\text {th }}$ century BCE led to the monetarization of the cults. The mercantile logic and money-oriented society shaped the transaction between the worshippers and the cults of Demeter. The relationship to deities was regulated by 'do ut des', i.e. one gives something so that the deity may give something in return. The epigraphic sources from the $5^{\text {th }}$ and $4^{\text {th }}$ centuries BCE give insight into the finances of the Eleusinian cult and illustrate the extent of monetarization of the cult of Demeter. Animal sacrifices, aparche, and priestly share were also partially replaced by money. Coins found at various sanctuaries of Demeter were deposited as votives and treasuries.
\end{abstract}

\begin{abstract}
Riassunto
La monetizzazione dei mercati subì nel $\mathrm{V}$ sec. un'accelerazione, portando, a sua volta, a una monetizzazione dei culti. La logica commerciale e una società orientata alla monetizzazione modificarono le relazioni tra i devoti e i culti di Demetra. II rapporto con le divinità era regolato da un "do ut des", e quindi dall'inclinazione a offrire qualcosa alla divinità per ottenere altro in cambio. Le fonti epigrafiche del $\mathrm{V}$ e del IV secolo offrono indicazioni relative alle finanze del culto eleusino e alla monetizzazione del culto di Demetra. I sacrifici animali, aparche e porzioni sacerdotali furono parzialmente sostituiti da compensi in denaro. Monete reperite in vari santuari di Demetra erano depositate come ex-voto e tesori.
\end{abstract}

\section{Keywords}

Coin hoard • fees - aparche • priestly share Eleusinian Mysteries • Demeter

Parole chiave

Moneta - imposta - aparche • porzioni sacerdotali - Misteri eleusini - Demetra

.... and the initiated bring their tribute of a coin to the goddess,

as lovers do to a mistress.

Clement of Alexandria, Exhortation of the Greeks 2

\section{Introduction}

$\mathrm{P}$ ausanias (3.12.3) tells us that one paid with oxen, slaves, and ingots of silver and gold before coins were used as currency. ${ }^{1}$ In pre-monetary society, the exchange of items was commonplace. Food, animals, goods, services, and ingots were used as a medium of exchange. Worshippers consecrated animals, goods, and ingots as a means of payment of fees for individual and collective cultic rituals performed in sanctuaries. The monetarization of the market has certainly accelerated the use of coins in cultic context. The monetarization of cultic services was especially useful for the temple economy and cultic officials. The temple and cultic officials had higher benefit from money than from goods or animals. Money can be accumulated and used for different purposes. Goods and animals do not offer these advantages. There is a process of interweaving between the polis and the cults. The polis determined the features 
of the cults, organized festivals, and fixed temple taxes and fees for different cultic services. The polis has also accelerated the monetarization of the cults.

Clement of Alexandria ( $2^{\text {nd }}$ century CE) describes in Exhortation of the Greeks 2 the mysteries of Demeter performed at Alexandria and mentions that the initiates gave a coin to the goddess. Commercialized salvation was not only offered at Alexandria but also in other cities, especially at Eleusis, where the most significant mysteries in ancient Greece were performed in honour of Demeter and Persephone. The mysteries of Demeter and Persephone offered a better afterlife for those who were initiated into the Eleusinian Mysteries. Epigraphic sources from Eleusis and Athens mention fees imposed on all citizens and on the member cities of the Delian League. Fees are also attested by epigraphic evidence for various sanctuaries of Demeter and Persephone in other Greek cities. The income from the temple taxes and fees for different cultic services covered up one part of the funding of the sanctuaries and the income of cultic officials.

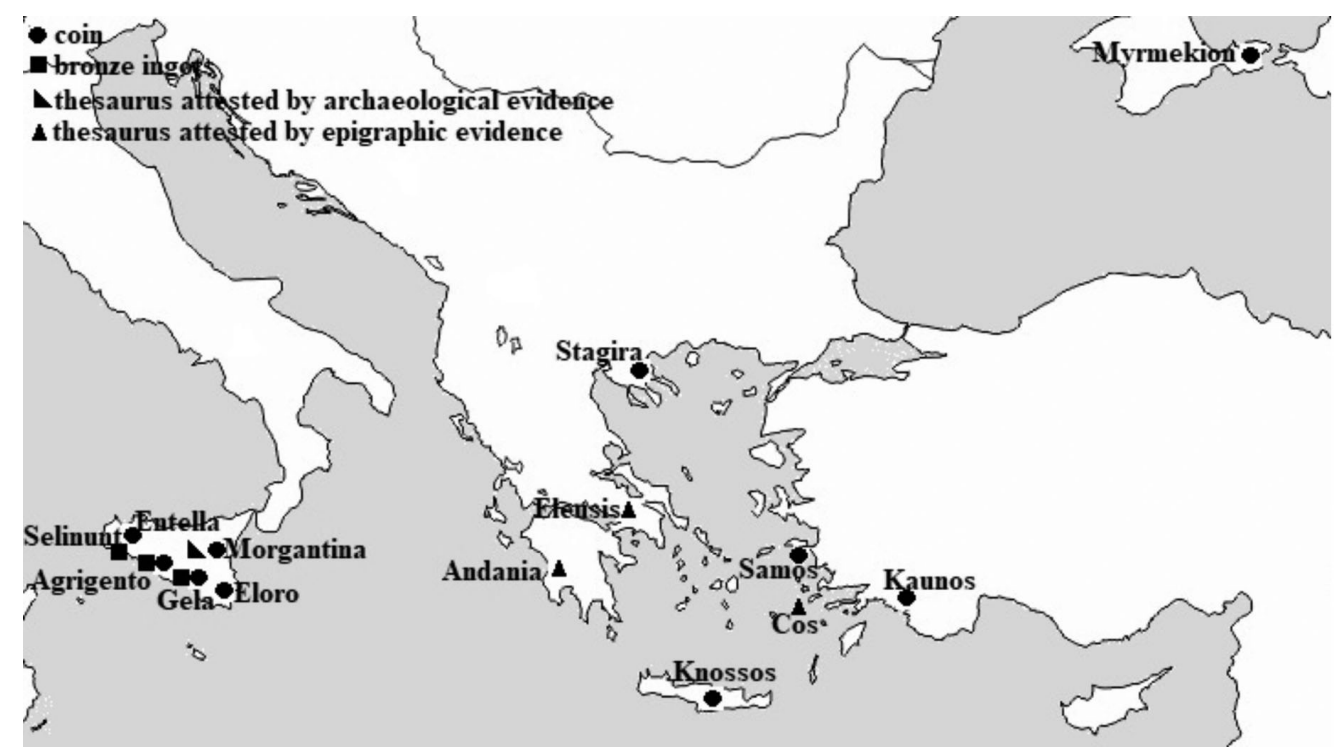

Fig. 1. Coins, bronze ingots, and thesaurus attested by archaeological and epigraphic evidence for the sanctuaries of Demeter (map edited by author)

This paper explores a number of epigraphic ${ }^{2}$ and archaeological sources that illustrate the shaping of the cult of Demeter and Persephone by commercial transactions, the income from the Eleusinian Mysteries, aparche, and coins deposited at various sanctuaries of Demeter. The first part of the paper deals with ingots and coins in gold, silver, bronze, and copper unearthed at the sanctuaries of Demeter (Fig. 1). The second part deals with thesauroi and their use attested by archaeological and epigraphic sources for the sanctuaries of Demeter. The third part analyses epigraphic material on the income from the Eleusinian Mysteries and aparche paid by the members of the Delian League. As it would go beyond the scope of this paper, only a few inscriptions on the finances of the sanctuary of Demeter and Persephone at Eleusis will be analysed.

2 The translations are mine, if not indicated otherwise. 
Metal ingots, metal objects, and jewellery made of metal were used as pre-monetary currency during the Archaic and earlier periods. Ingots and metal objects were consecrated by single worshippers and by the poleis at sanctuaries. Ingots were not only consecrated as votives but also used as means of payment for cultic services. The consecration of ingots is not restricted to the Archaic and earlier periods. A decree dating to the late $3^{\text {rd }}$ century BCE concerns the dedication of silver ingots and coins by the polis at the sanctuary of Amphiaraos in Oropos (IG VII 303; Epigr. tou Oropou 324). This inscription illustrates that metal was also dedicated in later periods. Ingots and metal objects dedicated at sanctuaries were sold or used for manufacturing of metal objects.

Bronze ingots were found at various sanctuaries, such as in Eloro, Monte San Mauri di Caltagirone, Gela, Himera, Selinunt, and Agrigento. ${ }^{3}$ Most sanctuaries, where bronze ingots were found, were dedicated to deities linked to agricultural fertility and to chthonian elements. ${ }^{4}$ Bronze ingots were unearthed at the sanctuaries of Demeter in Eloro, Gela, Selinunt, and Agrigento. ${ }^{5}$ The deposition of metal objects and ingots is more commonplace for the sanctuaries of Demeter in Western Greece than for her sanctuaries in other regions. Single metal objects are attested for some sanctuaries of Demeter in mainland Greece, Western Asia Minor, and on the Greek islands. The number of metal votives is, therefore, significantly high at the Western Greek sanctuaries of Demeter.

\begin{tabular}{|c|c|c|c|c|c|c|c|c|}
\hline & & & & उCE & & & & \\
\hline & 700 & 600 & 500 & 400 & 300 & 200 & 100 & $\rightarrow$ \\
\hline Stageira & & & & 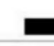 & & & & \\
\hline Kaunos & & & & & a & & & \\
\hline Myrmekion & & & & ש & & & & \\
\hline Knossos & & & & & & & & 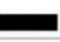 \\
\hline Entella & & & & & & & & 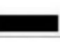 \\
\hline Morgantina & & & & & & & $\boldsymbol{\theta}$ & \\
\hline Gela Bitalemi & & 口 & & & & & & \\
\hline Gela Via Fiume & & & - & & & & & \\
\hline Agrigento santuario ctonio & & & & - & & & & \\
\hline Agrigento S. Anna & & घ & & & & & & \\
\hline
\end{tabular}

bronze ingots

Table 1. Coins and bronze ingots found at the sanctuaries of Demeter. The table illustrates the approximate period of dedication. ${ }^{6}$

3 De Angelis 2016, 251.

4 De Angelis 2016, 251.

5 Eloro (De Miro 2008, 66), Gela (Verger 2011, 26), and Agrigento (Fiorentini 1969, 72).

6 Stageira (Sismanidis 1999, 472-474), Kaunos (Bulba 2010, 654), Myrmekion (Butyagin, Chistov 2006, 77-80), Morgantina (STillwell 1959, 168; SjöQvist 1960, 78), Gela (Hinz 1998, 67; Orlandini 1965-67, 1-20; Id. 1966, 8-35; Id. 2008, 173; Verger 2011, 26; TARditi 2016, 59), and Agrigento (Hinz 1998, 82). 
The monetarization of the markets has its beginning in the $6^{\text {th }}$ century BCE. However, it is in the $5^{\text {th }}$ and following centuries that coins played an important role in the economy and cultic life. The deposition of coins in sanctuaries has also its beginning in the $5^{\text {th }}$ century BCE. More than 118 sanctuaries of Demeter are attested by archaeological evidence, ${ }^{7}$ but coins were only unearthed at few sanctuaries of the goddess (Fig. 1; Table 1): Myrmekion, Stageira, Samos, Kaunos, Knossos, Via Fiume at Gela, Morgantina, Eloro, Entella, and the santuario ctonio at Agrigento. ${ }^{8}$ The coins are made of gold, silver, bronze, and copper. In some sanctuaries, the low value bronze coins were deliberately deposited together with clay votives, jewellery, pins, and other objects made of bronze and iron. Coins found at various sanctuaries and sites were also low value coins used in day-to-day low value transactions. ${ }^{9}$ The find circumstances of coins at some sanctuaries of Demeter suggest that the coins were dedicated as votives and were not intended to be used for the expenses of the sanctuary. As illustrated in Table 1, the deposition of coins as votives ends in the late $2^{\text {nd }}$ and in the early $1^{\text {st }}$ centuries BCE. The dedication of clay votives also ends at most sanctuaries of Demeter in the $2^{\text {nd }}$ century BCE, indicating that the end of the deposition of coins as votives is linked to the end of dedication of clay votives. Some coins were intentionally deposited in hoards at some sanctuaries. In antiquity, many sanctuaries functioned as banks, where money and precious ingots were deposited. Gold and silver coins were deposited as treasury for later recovery in sanctuaries. Sometimes, the coins were for some reasons not retrieved. Picard states that bronze coins were seldom deposited as treasury due to their low material value and to the demonetization of bronze coins after a period. ${ }^{10}$

As the relationship of the worshipper to the deities was regulated by 'do ut des', the main aim was that the worshippers gave money to the deity for his help. For this reason, it was not important for the worshippers whether the coins, which they consecrated as payment for services, were deposited in the sanctuary or used for the running cost of the shrine. Cultic officials could deposit one part of the coins as votives and integrate the deposition into a ritual. Nowadays, coins are thrown into some public wells. Regularly, one part of the coins is collected by officials. Pausanias (1.34.4) records that worshippers, who were cured of a disease, throw silver and coined gold into the spring of Amphiaraos that was located close to the sanctuary of Amphiaraos in Oropos. The silver and gold coins were consecrated as fees. Worshippers consecrated money in a designated place within the temenos. The coins dedicated at this place were retrieved by cultic officials. Only at some sanctuaries, one part of the coins was deposited as votives. This is the reason why several thousand coins dedicated over a long period were not found scattered over the temene.

The sanctuary of Demeter at Gela Bitalemi was established in the $7^{\text {th }}$ century BCE and abandoned in the late $5^{\text {th }}$ century BCE. The end of the cult at Bitalemi was not the end of the cult of Demeter at Gela, as the goddess was worshipped at her other sanctuaries in the same

7 Karatas 2015, appendix table 3.

8 Myrmekion (Butyagin, Chistov 2006, 77), Stageira (Sismanidis 1999, 472-474), old Samos (Archaeological Museum of Pythagorion), Kaunos (Bulba 2010, 654), Knossos (Jackson 1973, 99-113), Via Fiume at Gela (Orlandini 1966, 34sqq; Kron 1992, 634sq; Hinz 1998, 67), Eloro (Uhlenbrock 1988, 135), Entella (Frey-Kupper 2016, 285-294), and the santuario ctonio at Agrigento (Kron 1992, 635; Hinz 1998, 82).

9 For further discussion on coins found at different places in the Greek world, see also ÇıZMELI-ÖGüN, MarCELLESI 2011, 197sqq; ButCher 2016, 225sqq.

10 PiCARD 2016, 82. 
city. The strata of the site at Bitalemi is divided into 5 layers (Fig. 2). ${ }^{11}$ The stratum 5 is the oldest layer and votives found in this layer date to the second half of the $7^{\text {th }}$ and to the first half of the $6^{\text {th }}$ century BCE. ${ }^{12} 70 \%$ of the votives, metal objects, and ingots were found in the stratum $5 .{ }^{13}$ Votive dedication at this site ceased in the $5^{\text {th }}$ century BCE. Orlandini unearthed 31 deposits in the stratum 5 containing each between $0.350-11.70 \mathrm{~kg}$ metal objects and ingots. ${ }^{14}$ The bronze ingots were not all collected and deposited together in the same pit but in 29 different deposits. ${ }^{15}$ The high number of deposits, where bronze ingots were deposited, and the long period of dedication indicate that bronze ingots were collected over a period and deposited together with other votives dedicated during the same period. Not only a high number of metal ingots were unearthed in the stratum 5, but also many bronze and iron objects, e.g. jewellery, agricultural tools, and knives. Metal objects such as agricultural tools were dedicated to Demeter, as she was a goddess of agricultural fertility. But these objects and other metal objects had a material value and were dedicated as valuable votives. ${ }^{16}$
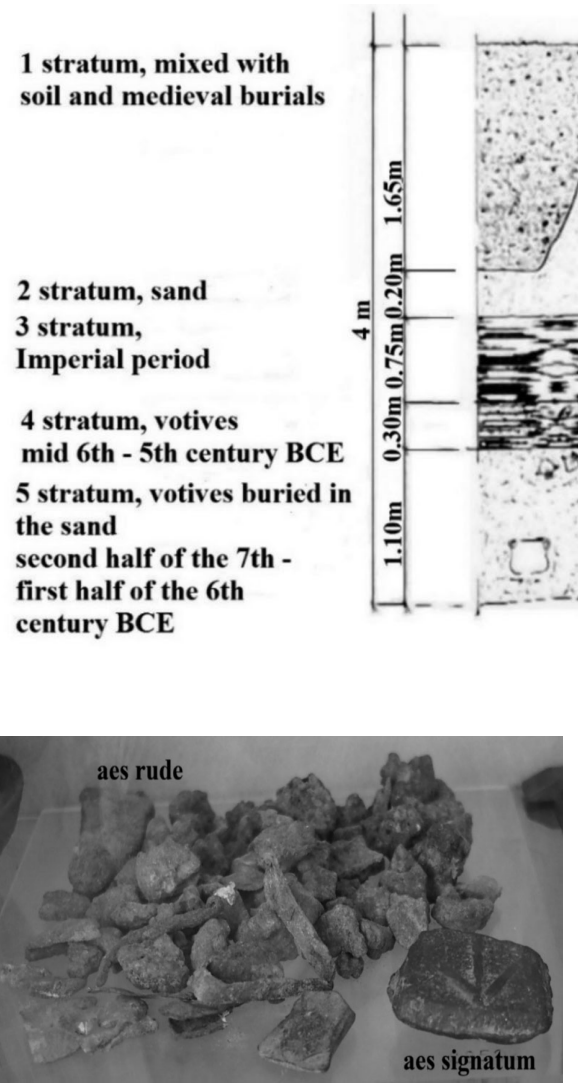

Fig. 2. Strata of the sanctuary of Demeter at Gela Bitalemi (Orlandini 1966, pl. 2, fig. 2; drawing edited by author)

Fig. 3. Bronze aes rude and aes signatum dating to the 6th century BCE found in the layer 5 of the sanctuary of Demeter at Gela Bitalemi (Museo Archeologico Regionale di Gela; photo by author)

11 Orlandini 1965, 1-3; Id. 1966, 8sqq, pl. 2, fig. 2.

12 ORLANDini 1965, 2.

13 Hinz 1998, 58.

14 ORLANDINI 1965: 4-17.

15 Bronze ingots were found in deposits 2, 4-21, 22, 24-31 (OrLANDini 1965, 4-16).

16 See also SEAFORD 2004, 139, fn. 87. 
The ingots found at Gela Bitalemi include 709 single bronze ingots dating to the $6^{\text {th }}$ century BCE. ${ }^{17}$ According to Verger, approximately 610 bronze ingots $(84 \mathrm{~kg})$ were found at this site. ${ }^{18}$ The total weight of bronze found at Bitalemi is $102 \mathrm{~kg} .{ }^{19}$ Tarditi states that the bronze ingots have a weight of $110 \mathrm{~kg} .{ }^{20} 709$ single bronze ingots found at this site are composed by 704 bronze ingots and bars (Fig. 3). ${ }^{21}$ The bronze ingots and bars are called aes rude, des formatum, and aes signatum. ${ }^{22}$ The bronze aera formata from Bitalemi has rounded or oblique sides. ${ }^{23}$ The letters $\Sigma \mathrm{H}$ are engraved on one of the aera formata. ${ }^{24}$ The aes signatum from Bitalemi is considered to be one of the earliest examples dating to the second half of the $6^{\text {th }}$ century BCE. ${ }^{25}$ The aes signatum from Bitalemi weighs $670 \mathrm{gr}$ and has an ornament on each side that depicts leaves (Fig. 3). If we calculate 2-3 drachmas per kilo, $100 \mathrm{~kg}$ bronze had a value of 200-300 drachmas. ${ }^{26}$ Approximately $84 \mathrm{~kg}$ of ingots consists of bronze ingots between $5 \mathrm{gr}$ and $3,3 \mathrm{~kg} .{ }^{27}$ $72,5 \%$ of the ingots are less than $100 \mathrm{gr}^{28}$ Depending on the weight, each ingot had at least a value of ca one obol. The single bronze ingots were probably consecrated as votives or as fees for cultic rituals by single worshippers.

Another sanctuary of Demeter at Gela is situated in Via Fiume. The shrine is located outside the city walls and has two oikoi. The archaeological material from this sanctuary dates to the $6^{\text {th }}-4^{\text {th }}$ centuries BCE. ${ }^{29} 900$ silver coins dating to 500 BCE were found deposited into a vase. ${ }^{30}$ Depending on the weight of each coin, 900 silver coins were worth several hundred drachmas. Coins dating to later periods were apparently not found at this site. The silver coins were presumably deposited as a treasury. As mentioned, precious metals and money were deposited as treasuries in some sanctuaries. Especially major sanctuaries were used for the deposition of treasuries. Such sanctuaries offered security for the stored treasuries, as they were generally located within the settlements and had guardians. The small sanctuary in Via Fiume is located outside the city walls and did not offer enough security for the deposition of a high quantity of coins. $5^{\text {th }}$ century BCE is marked by several territorial disputes between Gela and other cities. The silver coins were probably deposited during the political turbulence and it was aimed to recover it later. As the shrine existed for more than 100 years, it is not obvious why the silver coin hoard was not retrieved.

17 Hinz 1998, 58; Orlandini 2008, 173sq; Verger 2011, 19; Tarditi 2016, 59.

18 Verger 2011, 25.

19 VERGER 2011, 25.

20 TARDITI 2016, 50.

21 TARDiti 2016, 59, fig. 30.

22 Aes rude (aera rudia, plural): an irregular rough piece of bronze. Aes formatum (aera formata, plural): a bronze bar of a certain shape. Aes signatum (aera signata, plural): a stamped bronze bar.

23 TARDITI 2016, 59.

24 Orlandini 1965, 20; Verger 2011, 26; Tarditi 2016, 59.

25 TARDITI 2016, 60.

26 2-3 drachmas per kilo of bronze (PrICE 1968, 103). Based on $I G \mathrm{II}^{2} 1675$, Murray calculated a price of 60 drachmas and 1.5 obols for one talent of bronze $(1985,144)$.

27 Verger 2011, 25.

28 Verger 2011, 25.

29 Hinz 1998, 66sq.

30 Hinz 1998, 67; Orlandini 2008, 173. Coins are also attested for the sanctuary of Demeter in Carrubazza at Gela (Hinz 1998, 66). 

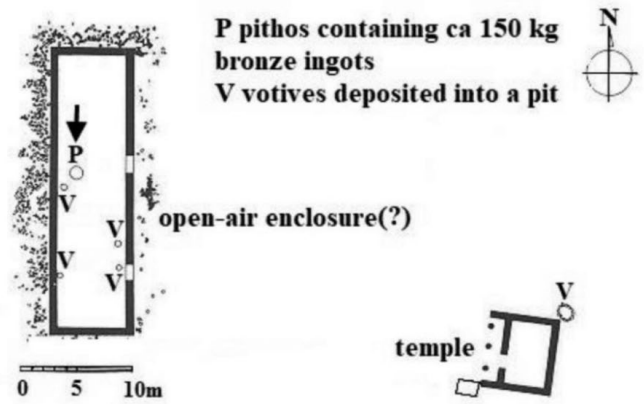

open-air enclosure(?)

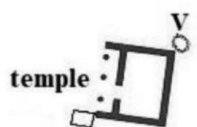

Fig. 4. Plan of the sanctuary of Demeter at $S$. Anna in Agrigento (Hinz 1998, 72, fig. 8; plan edited by author)

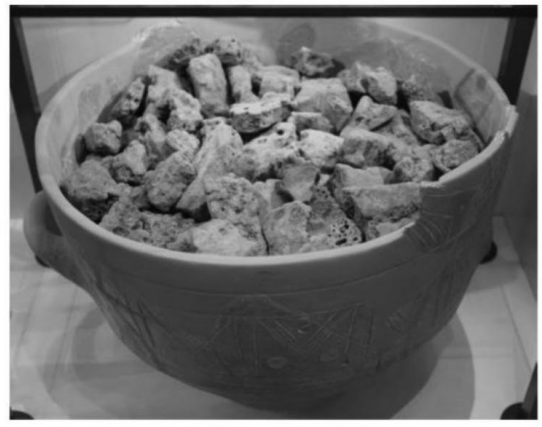

Fig. 5. Bronze ingots found in a pithos at the sanctuary of Demeter of S. Anna in Agrigento (Archaeological Museum of Agrigento; photo by author)

One of the sanctuaries of Demeter in Agrigento is located at S. Anna. The cult of Demeter at S. Anna began in the $6^{\text {th }}$ century BCE and existed until the $3^{\text {rd }}$ century BCE. ${ }^{31}$ The sanctuary has a temple and an open-air enclosure (Fig. 4). ${ }^{32}$ Several pits containing clay votives, lamps, and metal objects dating to the $6^{\text {th }}$ and $5^{\text {th }}$ centuries BCE were unearthed in the open-air enclosure, ${ }^{33}$ which was apparently used for the deposition of votives. This is a practice attested for several sanctuaries of Demeter located in Doric cities, e.g. Rhodes town, Cnidus, and Halicarnassus. A pithos - 48 $\mathrm{cm}$ in height and $59 \mathrm{~cm}$ of diameter - from local production and dating to the $6^{\text {th }}$ century BCE was unearthed in one of the pits located in the open-air enclosure (Fig. 5). ${ }^{34}$ Two third of the pithos was placed into the pit. ${ }^{35}$ It recalls the thesaurus found at the central sanctuary of Demeter in Morgantina. The pithos was used as a kind of collection vessel for the consecration of bronze ingots from the beginning of the cult of Demeter at this site. The pithos contains $150 \mathrm{~kg}$ bronze ingots and several coins. ${ }^{36} \mathrm{~A}$ cup, two iron knives, and a key were placed on the pithos. ${ }^{37}$ The size and the shape of the bronze ingots suggest that they were used as aera rudia (Fig. 5). If the price for $1 \mathrm{~kg}$ of bronze was ca. 2-3 drachmas (see Table 2), $150 \mathrm{~kg}$ had a value of ca. 300-425 drachmas. The bronze ingots were probably dedicated by single worshippers and collected in this pithos. We can assume that a higher number of ingots were dedicated at this site in the $6^{\text {th }}$ and $5^{\text {th }}$ centuries BCE. A significant part of ingots consecrated at this site was probably melted down or sold. The ingots found in the pithos were presumably deposited by cultic officials in the $5^{\text {th }}$ century BCE when the offering of ingots and as a means of payment for services came to an end. The deposition of a cup, two knives, and a key on the pithos also indicates that the ingots were deposited solemnly as votives by cultic officials. From the $5^{\text {th }}$ century BCE onwards, the payment in ingots was replaced by coins at the sanctuary in S. Anna that continued to exist for ca. 200 years. Coins consecrated between the $5^{\text {th }}$ to $3^{\text {rd }}$ centuries BCE were not deposited in the precinct.

31 Fiorentini 1969, 63; Hinz 1998, 71, 74.

32 Hinz believes that the building was an open-air enclosure $(1998,72)$.

33 Fiorentini 1969, 70-72.

34 Hinz 1998, 71sq.

35 Hinz 1998, 73.

36 Fiorentini 1969, 72; Hinz 1998, 73. According to Fiorentini, the pithos contained $149.80 \mathrm{~kg}$ bronze ingots $(1969,72)$.

37 Fiorentini 1969, 72; Hinz 1998, 73. 


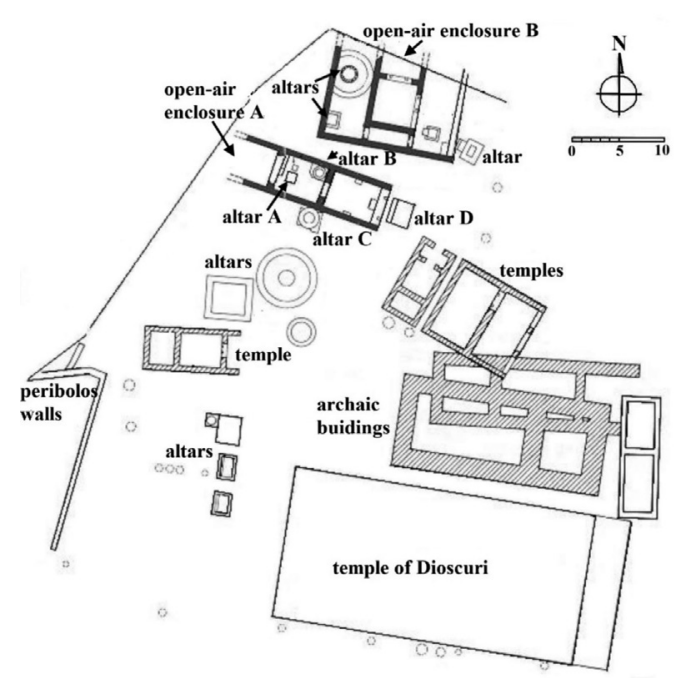

Fig. 6. Plan of the sanctuary of the chthonian deities at Agrigento (Hinz 1998, 80, fig. 12; plan edited by author)

The sanctuary of the chthonian deities at Agrigento is situated on the acropolis called the Valle dei Templi, where numerous monumental sanctuaries are located. The sanctuary of the chthonian deities, which has its beginning in the $6^{\text {th }}$ century BCE, has three temples, two open-air enclosures, circular altars with recesses, and rectangular altars (Fig. 6). The open-air enclosure A has a structure like a temple and has three rooms. ${ }^{38}$ The initial height of the walls of the open-air enclosure $\mathrm{A}$ is not known, as only two rows of the walls are preserved (Fig. 7). The significant size of the stone blocks used for the walls of the open-air enclosure A suggests that the walls were presumably high. It cannot be determined whether the entrance of the open-air enclosure A was in the south-east or in the north-west, as the thresholds giving access to the rooms are not preserved.

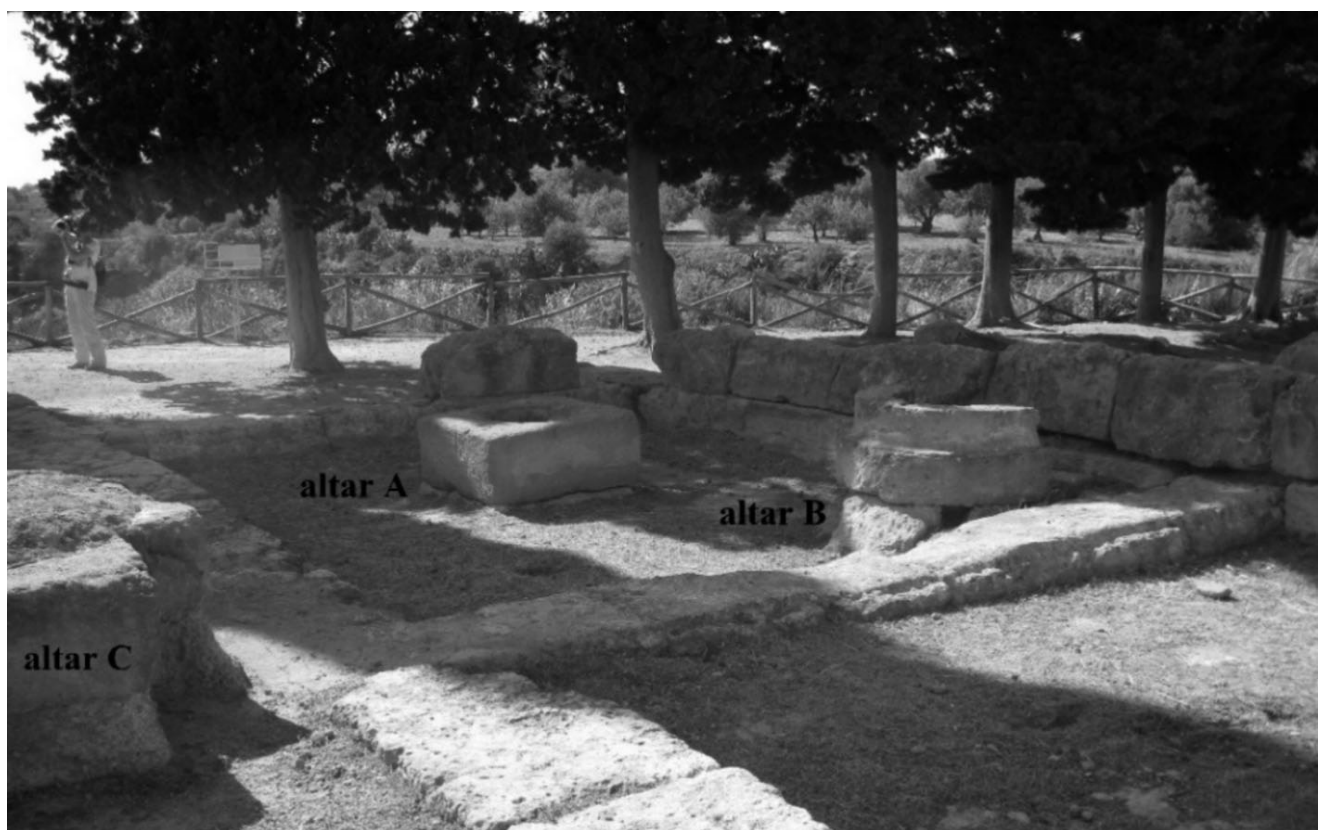

Fig. 7. The open-air enclosure at the sanctuary of the chthonian deities in Agrigento. Coins were deposited into the recess of the altar A (photo by author)

38 For this enclosure, see also Hinz 1998, 81-82. 

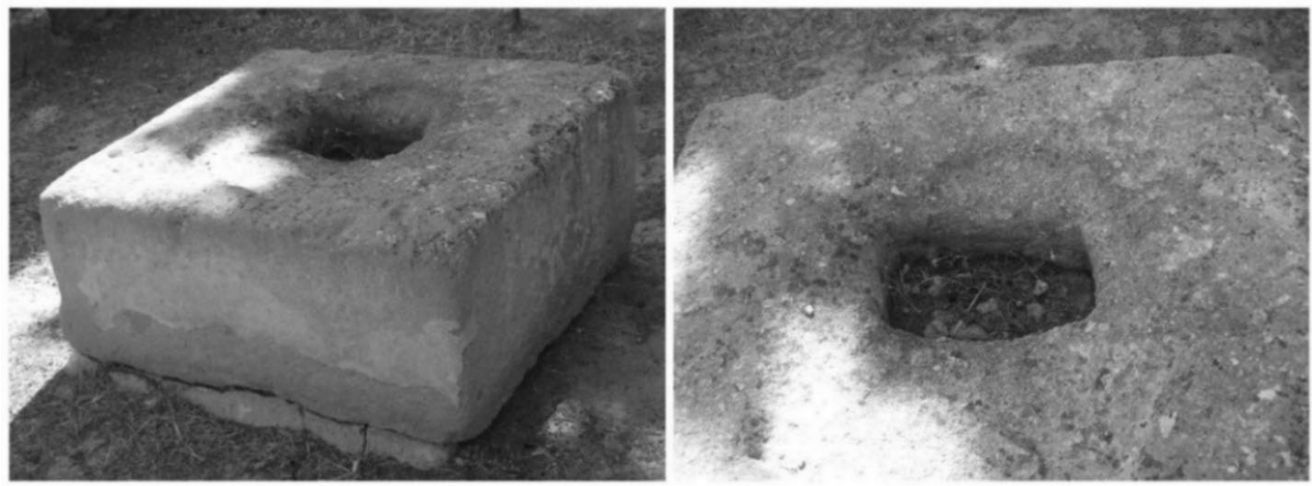

Fig. 8. Coins found in the cavity of the altar A located in the open-air enclosure A at the sanctuary of chthonian deities in Agrigento (photo by author)

A small rectangular stone altar (altar A) with a recess is situated in the western room of the open-air enclosure A (Fig. 8). A circular stone altar with a large recess is also situated in the same room (altar B). The recesses of both altars were used for libation. A few coins dating to the $4^{\text {th }}$ century BCE were found together with bronze objects and burnt piglet bones in the cavity of the altar A. ${ }^{39}$ The small size of the cavity indicates that it was the intention of the dedicator to put selected offerings into it (Fig. 8). Coins were also deposited together with piglet bones at the sanctuary of Demeter in Kaunos. ${ }^{40}$ If a large number of votives were deposited into the earth, single coins can be deposited accidentally. This may be the case with a few coins found at the sanctuary of Demeter at Eloro. ${ }^{41}$ Especially low-value small coins made of bronze or copper were deposited accidentally or intentionally with votives. Carthaginians destroyed Agrigento in 406 BCE. In the following centuries, Agrigento and its sanctuaries lost their significance. The coins, bones, and bronze objects were probably deposited into the recess of the altar $\mathrm{A}$ as offering or as part of a ritual performed by cultic officials or worshippers before the open-air enclosure A was abandoned in the $4^{\text {th }}$ or $3^{\text {rd }}$ century BCE. ${ }^{42}$

Four sanctuaries of Demeter are located on the acropolis of Morgantina that was used for sacral and public buildings from the $6^{\text {th }}$ century BCE onwards. In 459 BCE, Morgantina came under the rule of Syracuse. It is in the $5^{\text {th }}$ century BCE that the sanctuaries of Demeter were built at Morgantina. Coins dating to the $5^{\text {th }}-3^{\text {rd }}$ centuries BCE are attested for the central, south, north, and north annex sanctuaries of Demeter in Morgantina. Even if Morgantina began to mint its own coins in the $5^{\text {th }}$ century BCE, coins found at the sanctuaries of Demeter in Morgantina are from different Sicilian cities, especially from Syracuse. Epigraphic and literary sources are silent concerning the significance of the cult of Demeter at Morgantina for other Sicilian cities. Sanctuaries of Demeter are attested by archaeological evidence for 25 Sicilian cities. ${ }^{43}$ Like nowadays, people did not only visit the sanctuaries in their cities, but also those in other cities. It can, therefore, not be excluded that worshippers from Morgantina dedicated

39 Hinz 1998, 82.

40 Bulba 2010, 654.

41 DE Miro 2008, 60.

42 Hinz 1998, 84-88.

43 For the sanctuaries of Demeter in Sicily, see Hinz 1998. 
all or almost all coins from other Sicilian cities. Grandjean states that one is tended to think that foreign coins, which were not made of valuable metal and had less value, were discarded. ${ }^{44}$ Like at Argos, where Grandjean excavated, many coins found at various sanctuaries were bronze coins from other cities. The coins from other cities had a material value but were not always accepted as legal tender. The coins from Morgantina consecrated at the sanctuaries of Demeter were used for the running cost, whereas one part or all bronze coins from other cities were deposited as votives. Bronze coins from other cities, which were not used as legal tender, were melted down and manufactured. Depending on the weight, it provided a small income for the sanctuary.

Nine silver coins $\left(3^{\text {rd }}\right.$ century BCE) deposited in a jar were found in a room of the south sanctuary of Demeter and Persephone at Morgantina. ${ }^{45}$ Sjöqvist considers this type of jars as medicine bottles, as such bottles from Morgantina bear the inscription $\Lambda \Upsilon K I O N$ (lykion) and depict the head of Asclepius. ${ }^{46}$ Lykion is a plant used in medicine (Diosk. Mat.Med. 1.132). Sjöqvist has suggested that a worshipper dedicated the bottle with silver coins as an expression of his gratitude towards the goddess, ${ }^{47}$ suggesting that Demeter or Kore ${ }^{48}$ was worshipped as a healing deity at Morgantina. The bottle may also have been dedicated to Asclepius. Healing cults flourished during the Classical and later periods and ensured a high income for sanctuaries offering incubation and therapies. Healing aspect of the cult of Demeter, Kore, and Plouton was also emphasized during these periods. I.Didyma $496\left(2^{\text {nd }}\right.$ or $3^{\text {rd }}$ century CE $)$ provides evidence for incubation performed at the sanctuary of Demeter in Miletus. Incubation is also attested for the sanctuary of Plouton and Kore at Acharaca located in Nysa (Strab. 14.1.44). Money was paid as fees for incubation and various therapies offered at sanctuaries. The silver coins were paid for services offered at this shrine or dedicated as thanksgiving. The silver coins paid as fees for various services may have been collected by cultic officials in this bottle. The silver and gold coins from the sanctuaries of Demeter at Gela (Via Fiume) and Myrmekion were also put into a vase. Due to the high number of silver and gold coins found in vases at Gela and Myrmekion, the two coin hoards had a high material value, whereas 9 silver coins were only worth several drachmas. The 9 silver coins were deposited as votives, but not as treasury.

19 Greek coins ( $3^{\text {rd }}$ century BCE) from Sicilian cities (Syracuse and Agrigento), 9 Roman coins $\left(3^{\text {rd }-2} 2^{\text {nd }}\right.$ centuries BCE), and several clay busts of Persephone were found in the same room, where the medicine bottle was deposited..$^{49}$ Apart from the coins in the medicine bottle, 56 coins were also found in the south sanctuary. ${ }^{50}$ The coins date to the $4^{\text {th }}-3^{\text {rd }}$ centuries BCE and are from Agrigento, Alaesa, Mamertine, Syracuse, Rome, and Carthage. ${ }^{51}$ These coins were also consecrated as payment for cultic services and deposited by cultic officials or by worshippers.

44 Grandjean 2016, 59.

45 SjöQvist 1960, 78; Buttrey, Erim, Groves, Holloway 1989, 164, no. 29.

46 SJöQvist 1960, 78, pl. 19.

47 SJöQvist 1960, 78.

48 From the Hellenistic period onwards, the name Kore was associated with positive aspects, whereas Persephone was more linked to the underworld.

49 SJöQvist 1960, 78sq.

50 Buttrey, Erim, Groves, Holloway 1989, 165sq, no. 30.

51 Buttrey, Erim, Groves, Holloway 1989, 165sq, no. 30. 
A single coin is attested for the north sanctuary, ${ }^{52}$ and 18 coins for the north sanctuary annex of Demeter at Morgantina, which were found in three different rooms. ${ }^{53}$ These coins also date to the $4^{\text {th }}-3^{\text {rd }}$ centuries BCE and are from Agrigento, Syracuse, Tauromenium, Leontini, Alaesa, and Panormus. ${ }^{54}$ The significantly small number of coins found at these shrines suggests that they were left accidentally in the temene.

The sanctuary of Demeter at Stagira was established in the $6^{\text {th }}$ century BCE. The shrine has two simple oikoi and a circular building $(11 \mathrm{~m}$ diameter) dating to the Archaic period (Fig. 9). Altogether 79 coins dating to the Classical period were found in the western part of the sanctuary of Demeter at Stageira deposited into a pit together with bronze arrowheads and bullets. ${ }^{55} \mathrm{~A}$ few bronze coins dating to 394-250 BCE and arrowheads are also attested for the sanctuary of Demeter at old Samos. ${ }^{56}$ Arrowheads are linked to the army, but they also had a material value. Arrowheads, which are also attested for the sanctuaries of Demeter at Knossos and Cyrene,${ }^{57}$ may have been dedicated by any worshippers as votives. Apart from three coins in silver, the other coins found at Stagira are in copper. ${ }^{58}$ Coins were also found in the circular building. Sismanidis has suggested that the circular building was a Thesmophorion, as it has similarities with the sanctuary of Demeter at Pella. ${ }^{59}$ The sanctuary of Demeter at Pella is a circular open-air shrine surrounded by a wall. Several sacrificial pits are situated in this circular structure at Pella. The walls of the sanctuary of Demeter at Pella and that of the circular building at Stagira are low. The circular building at Stagira was presumably an open-air enclosure that offered space for a few people. Such a small building does not offer enough space for the celebration of the Thesmophoria. Clay figurines, vessels, lamps, metal object, and coins were deposited into three pits cut into the rocky ground of the circular building at Stagira.${ }^{60}$ One of the pits of the circular building contains 30 coins, bronze arrowheads, and bullets, which were deposited as votives. The coins date to the late Classical and to the early Hellenistic periods. The bronze and copper coins found at this site did not have a high material and monetary value. The coins bear the names of Philip (7 coins), Alexander the Great (11 coins), Antigonus Gonatas (3 coins); seven coins are from Amphipolis and two from Chalcidice. ${ }^{61}$ Not only most of the coins found at this site bear the names of Philip and Alexander the Great but also $33 \%$ of the excavated coins from Stageira. ${ }^{62}$ Stageira minted its own coins from the $6^{\text {th }}$ century to 480 BCE. ${ }^{63}$ From the second half of the $4^{\text {th }}$ century BCE onwards, coins issued in Macedonian

52 Buttrey, Erim, Groves, Holloway 1989, 159sq, no. 19.

53 Buttrey, Erim, Groves, Holloway 1989, 158sq, nos. 15-18.

54 Buttrey, Erim, Groves, Holloway 1989, 158sq, nos. 15-18.

55 Sismanidis 1999, 473-474.

56 Most of the coins found at the sanctuary of Demeter at old Samos town are Samian coins and a single coin is from Cyme (Archaeological Museum of Pythagorion). As the votives found at this site have not yet been published, it is not recorded how the coins were deposited. All bronze coins from this site are very small. Due to the small size and number of the bronze coins, they were probably deposited accidentally in the temenos of Demeter.

57 Knossos (Coldstream 1973, 157, no 219) and Cyrene (White 1984, 51).

58 Sismanidis 1999, 473.

59 Sismanidis 2003, 81.

60 BCH 119, $1995,967$.

61 Sismanidis 1999, 473sq.

62 Gatzolis, Psoma 2016, 92.

63 Gatzolis, Psoma 2016, 94. 
kingdom were in use as legal tender in Chalcidice. ${ }^{64}$ This explains why most coins found at this site bear the names of the Macedonian rulers. The inscriptions ФI $\Lambda$ IПО (Philippou) and $\mathrm{K} \Lambda \mathrm{EOBO} \Lambda \mathrm{O} \Upsilon$ (Kleoboulou) engraved on bullets indicate that these bullets were in use during the reign of Philip of Macedonia or during the destruction of Stageira in 348 BCE. ${ }^{65}$ Philip II reigned between 359-336 BCE, Alexander the Great between 336-323 BCE, and Antigonus Gonatas between 277-239 BCE, suggesting that the coins were consecrated over a period of ca. 100 years. Most of the coins found in the circular building were dedicated after the destruction of Stageira.
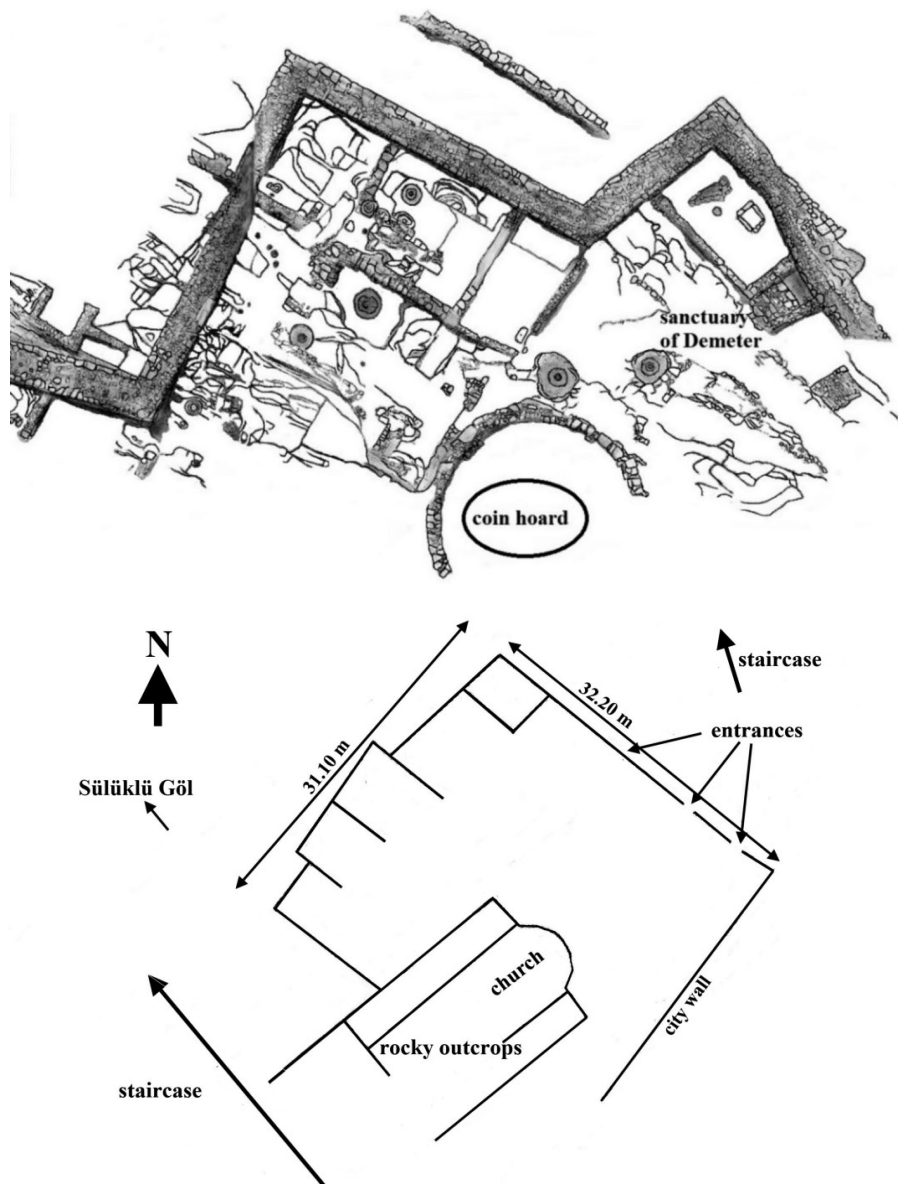

Fig. 9. Plan of the sanctuary of Demeter at Stageira (Sismanidis 2003, 79, fig. 81; plan edited by author)

The open-air sanctuary of Demeter at Kaunos was founded in the $6^{\text {th }}$ century BCE (Fig. 10). ${ }^{66}$ Votives deposited into the cavities of the rocky outcrops date from the $6^{\text {th }}$ to $1^{\text {st }}$ centuries

64 Gatzoulis 2011, 192sqq.

65 Sismanidis 1999, 472sq.

66 Bulba 2010, 649. For the sanctuary of Demeter at Kaunos, see also IşıK (2000, 229-240; Id. 2010, 88-96) and Bulba (2008, 109-114). 
BCE. ${ }^{67}$ Excavations carried out at this shrine in 2009 and 2010 brought to light $291^{68}$ silver and a few bronze coins. ${ }^{69}$ The coins were deposited together with clay figurines, lamps, and piglet bones. ${ }^{70} 110$ silver coins were found deposited together with piglet bones into a cavity. ${ }^{71}$ The coins are from different cities: 18 coins are from Kaunos, 204 from Kasolaba (Caria), 37 from Hydai (Caria), 8 from Rhodes, 6 from Euromus (Caria), and 5 from Magnesia on the Maeander (Ionia). ${ }^{72}$ Coins found in different sites at Kaunos are made from bronze. ${ }^{73}$ As far as I am aware, another silver coin hoard is not attested for other sites in Kaunos. The silver coins from Kaunos, Kasolaba, ${ }^{74}$ Euromus, and Hydai date to the $5^{\text {th }}$ and $4^{\text {th }}$ centuries BCE. ÇizmeliÖğ̈̈n and Marcellesi point out that the bronze coins were in use from the $4^{\text {th }}$ century BCE onwards. ${ }^{75}$ It explains partially why a high number of silver coins was consecrated at this shrine.

As most coins are from other cities, the question arises whether the cult of Demeter at Kaunos was also worshipped by people from other Carian cities. Coins from different cities circulated in other cities, since cities had political and economic relations with each other. Coins from some cities were also used as currency or changed in an office of the polis. Inscriptions from Kaunos and other cities do not mention the cult of Demeter at Kaunos, which had presumably local significance and the coins were dedicated by local people. Bresson states that "the system of coinage precious metals is to be sought in the universal character of coins as a means of payment". ${ }^{76}$ Silver coins from other cities were probably accepted as means of payment made by weight between merchants, but not as legal tender in everyday life, as Kaunos had its own currency. Silver coins from other cities had a certain material value and were dedicated by local worshippers as valuable objects at the sanctuary of Demeter in Kaunos. As Demeter was mainly worshipped by women, it seems unlikely that merchants dedicated the silver coins. Therefore, the numerous clay male figurines found at the sanctuary of Demeter in Kaunos may indicate that the cult of Demeter was not restricted to women.

As the coins from the sanctuary of Demeter at Kaunos have not yet been published, the average weight of the coins is not known. If the coins from this site have an average weight of ca. 4 gr, each coin had a value of ca. 1 drachma and 291 coins were worth ca. 291 drachmas (for the price of silver, see Table 2). As the daily wage of a skilled worker was ca. 1 drachma, a silver coin was a valuable votive. If we assume that a silver coin, depending on its weight, was equivalent to the daily wage of a skilled worker, not all worshippers were able to consecrate a silver coin as fees for rituals. We can assume that these silver coins were not the only coins

67 Bulba 2010, 650-655.

68 See the following footnote.

69 See also Bulba 2010, 654.

70 Bulba 2010, 654.

71 Bulba 2010, 654.

72 I would like to thank Zeynep Çizmeli-Öğün, who kindly informed me about the coins found at the sanctuary of Demeter in Kaunos. An accurate analysis of coins from this site will be published by Z. Çizmeli-Öğün. For coins from the sanctuary of Demeter at Kaunos, see also Kaunos Çalışma Raporu 2010, 10sq.

73 Çizmeli-ÖĞün, MarCellesi 2011, 321.

74 The Carian city Kasolaba has not yet been located; however, the city is also known from the Athenian Tribute list (Descat 1997, 61, 66sq). For coins from Kasolaba dating to the $5^{\text {th }}$ century BCE, see Konuk $(2007,476$ sqq). It is suggested that these coins were issued by a Carian city, but it cannot be determined with certainty whether it was the Carian city Kasolaba that minted these coins.

75 Çızmeli-ÖĞüN, Marcellesi 2011, 298.

76 Bresson 2016, 269. 
consecrated over 500 years at this shrine. Coins in bronze or copper were certainly also consecrated as fees for cultic rituals. It was intended to deposit coins made from precious metal. One part of silver coins consecrated by worshippers in the $5^{\text {th }}$ and $4^{\text {th }}$ centuries BCE was deliberately selected for its deposition, and the other coins were used for the expenses of the shrine. The silver coins were deposited as votives, as they were deposited with bones and clay votives. A singularity of this coin hoard is that the coins were deposited together with piglet bones. Piglets were important for the cult of Demeter and were sacrificed at various festivals and by single worshippers. The coins may have been dedicated independently from piglet sacrifices or as a preliminary offering made to the goddess before sacrifices.

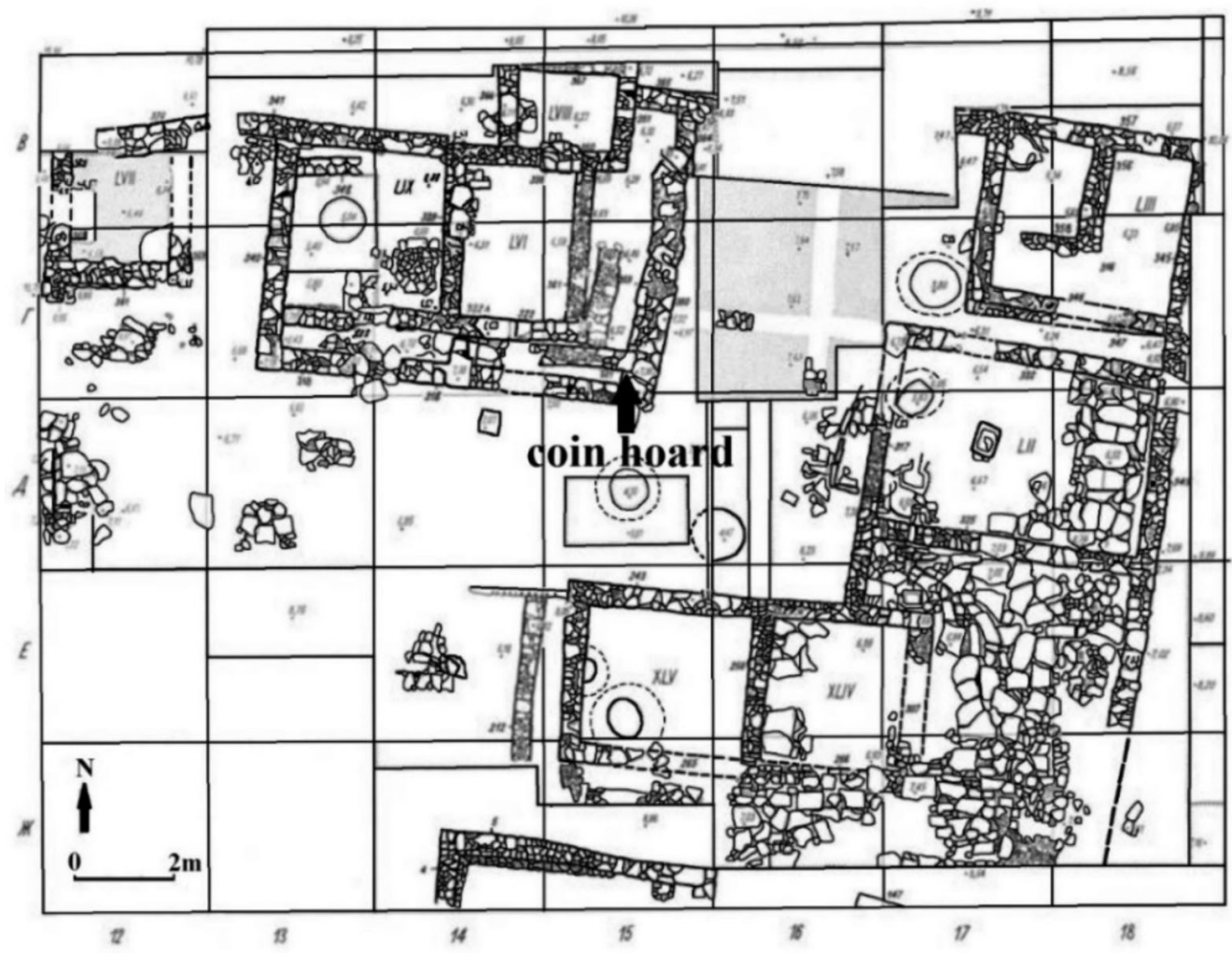

Fig. 11. Plan of the sanctuary of Demeter at Myrmekion (Butyagin, Chistov 2006, 102, fig. 21)

Myrmekion founded in the mid- $6^{\text {th }}$ century BCE was established by Panticapaeum, a city founded in the late $7^{\text {th }}$ or in the early $6^{\text {th }}$ century BCE by Greek colonists from Miletus. The excavations carried out in 2003 at the sanctuary of Demeter in Myrmekion by the Hermitage Museum (St. Petersburg) under the direction of Chistov brought to light a bronze olpe (21.5 $\mathrm{cm}$ in height) filled with 99 electrum staters from Cyzicus. ${ }^{77}$ A similar coin hoard is attested for

77 Butyagin, Chistov 2006, 77-131; Butyagin, Treister 2006, 133-146; Stancomb 2006, 373-374; OhlerICH 2009, 118. 
the sanctuary of Artemis at Epidaurus, where 92 gold coins dating to the $3^{\text {rd }}$ century BCE were found in a clay aryter. Other coins were not found in the sanctuary of Demeter at Myrmekion. Coins are also attested for the sanctuary of Demeter in Nymphaion. The coins were found together with clay votives deposited into a pit in a building dating to the $5^{\text {th }}$ century BCE. ${ }^{78}$
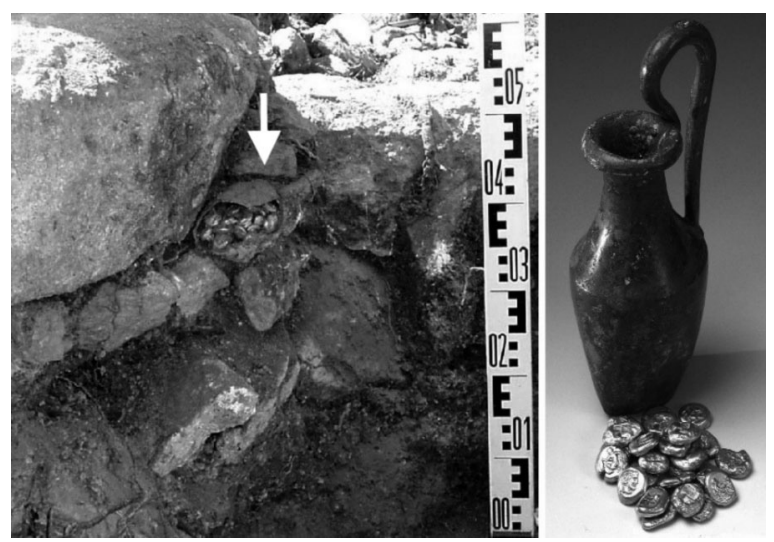

Fig. 12. Bronze olpe incorporated into the wall (left) of a naiskos at the sanctuary of Demeter in Myrmekion (Butyagin, Chistov 2006, 80, fig. 4), and after its restauration (right) (Butyagin, Treister 2006, 134, fig. 1)

The coin hoard found at Myrmekion was embodied into the wall 360 that was built in 370 BCE as part of a new building with an eschara that was probably used as a temple of Demeter (Fig. 11-12). ${ }^{79}$ This building was built on an ash-hill. Ashes, animal bones, and fragments of pottery found at this ash-hill indicate that it was used for burnt offering referred to as 'holokautoma' (ó $\lambda$ ок $\alpha u ́ \tau \omega \mu \alpha)$. Burnt offerings are well attested by archaeological evidence for various sanctuaries of Demeter. ${ }^{80}$ The eschara underlines the cultic significance and continuity of burning sacrifices at the sanctuary of Demeter in Myrmekion. The coins date to 500-400 BCE and the bronze olpe to the first half of the $5^{\text {th }}$ century BCE. ${ }^{81}$ As the bronze olpe with the coins was embodied into the wall of the new building, the coins and the olpe were initially dedicated to the same deity who was worshipped at the same place, where the new building was built. The olpe was dedicated more than 80 years before the construction of the wall 360 . All coins were probably collected in the olpe or deposited into the olpe before the wall was built. The olpe with the coins may have served as a foundation votive for the new temple of Demeter or deposited as a treasury.

78 OHLerich 2009, 118.

79 Butyagin, Chistov 2006, 77, 80.

80 Escherai were used for burning sacrifices. Sacrificed animals or food, such as cereals or cakes, were completely burnt. Escharai are attested for a number of sanctuaries of Demeter: Abdera (BHC 112, 1988, 662-664; BHC 113, 1989, 656; BHC 114, 1990, 800; BHC 116, 1992, 917), Dion (Pingiatoglou 2010, 183), Eleusis (Clinton 1988, 73, fig. 1), Xobourgo on Tenos (Koubou 2005, 28-29), Mytilene (Cronkite 1997, 43), Pergamon (Bohtz 1981, 16), Iasos (Levi 1969, 119; Bonifacio 2002, 14-15), Locri Epizephiri (Sabbione 2008, 204-205; Milanesio MaCri 2010, 334). Burnt offerings were also performed into a pit or on the earth as it is attested for the sanctuaries of Demeter at Neandria (Filges, Matern 1996, 70sqq), and Himera (Hinz 1998, 167). Burnt offerings performed over a long period on earth formed a hill.

81 Butyagin, Chistov 2006, 77, 133. 
Table 2. Approximate value of 99 electrum staters found at the sanctuary of Demeter in Myrmekion. Th following calculation is hypothetical

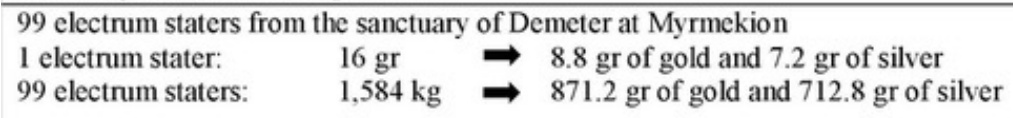

Price for silver and gold:

1 talent $(25.86 \mathrm{~kg}$ ) of bronze (Price 1968: 103) $=65$ drachmas

$65 \div 25.86=2.5$ drachmas for $1 \mathrm{~kg}$ of bronze

Ratio of silver to bronze: 100:1

Ratio of gold to silver (Lewis 1968: 105): 14:1

$\rightarrow 1 \mathrm{~kg}$ of silver $\quad=250$ drachmas

$1 \mathrm{gr}$ of silver $=1.5 \mathrm{obols}$

$\rightarrow 1 \mathrm{~kg}$ of gold $\quad=3,500$ drachmas

$1 \mathrm{gr}$ of gold $=21 \mathrm{obols}$

\title{
1 electrum stater
}

\author{
8.8 gr gold $\times 21=185$ obols \\ 7.2 gr silver $x 1.5=11$ obols \\ $\Rightarrow 196$ obols $=\mathbf{3 3}$ drachmas
}

99 electrum staters: $99 \times 33=\mathbf{3 , 2 6 7}$ drachmas

A singularity is that only electrums staters were deposited. An electrum stater was equivalent to 28 drachmas and to 7 Athenian tetradrachmas. ${ }^{82}$ An inscription from Olbia dating to the $4^{\text {th }}$ century BCE and found at the hieron Kalchedonion orders the purchase of Olbian coins at the ecclesia without fees (SEG 26:848, lines 9-22). ${ }^{83}$ A stater from Cyzicus was sold for 11,5 Olbian silver staters (SEG 26:848, lines 23-24). As illustrated in Table 2, an electrum stater from the sanctuary of Demeter in Myrmekion had probably a value of ca. 33 drachmas, and 99 electrum staters were worth 3,267 drachmas. Low value coins were also consecrated or paid as fees at this site, as not all worshippers were able to consecrate electrum staters. Apparently, only staters were deliberately collected over 100 years. The sanctuaries had reserves of precious objects and metals, which were used to finance the expenses of the cult. One part of the reserves was not used as circulating capital. The staters embodied into the wall of the oikos were presumably the reserves of the sanctuary. The deposition of the treasury into the wall offered security and gave the possibility to retrieve it any time. The sanctuary at this site existed at least for 100 years. Whatever the reason, the treasury was not retrieved later by cultic officials. During the long period, the sanctuary had different cultic officials. It may be that the treasury was not communicated to the next generation of cultic officials who served at this site.

196 bronze coins were unearthed in six votive deposit pits (deposits D, E, F, G, H, and $\mathrm{J})$ at the sanctuary of Demeter in Knossos. ${ }^{84}$ Most of the coins are from Knossos and were minted between 320 and 220 BCE. Single coins are from Gortyna, Itanos, Cydonia, Itanos, Argos, Athens, Cyrenaica, Paros, Rhodes, Antioch, and Nicomedia. ${ }^{85}$ The coins were deposited with statues, clay figurines, vessels, jewellery, and small finds made of silver, bronze, and iron. ${ }^{86}$ The votives date mainly to the Hellenistic period. Most of the 196 coins were minted and

82 Figueira 1998, 524sqq.

83 Related lammata: IosPE $\mathrm{I}^{2} 24$; IGDOlbia 14.

84 JACKSON published 164 coins $(1973,108)$.

85 JaCKSON 1973, 111-113.

86 JACKSON 1973, 188. 
consecrated over a period of ca. 100 years. On average, maximum two coins were consecrated per year, which is not significantly high. The bronze coins are small $(8-29 \mathrm{~mm})$ and were not high in value, suggesting that worshippers from different social classes were able to afford to consecrate bronze coins as fees for cultic services or dedicated as votives. Most of the coins were found in the deposit pits $\mathrm{H}$ and J. More than 300 gold, silver, bronze jewellery, and small finds were also found in the deposit pit $\mathrm{H}^{87}$ The content of the deposit pit $\mathrm{H}$ indicates that metal objects and coins were not deposited in all pits, but only in selected votive deposit pits. As the jewellery and metal small finds from this site have not yet been dated, it is not obvious to what extant coins have replaced metal objects or dedicated as votives alongside metal objects. Pausanias (7.22.3) mentions that the worshipper put a local coin, called a 'copper', and asked the deity a particular question he wished to put to him. Coins found at this site and at other sanctuaries were presumably consecrated as payment before a prayer addressed to the deity or at rituals. The coins were collected by cultic officials and used for the running of the shrine. Cultic officials deposited one part of the coins as votives alongside other metal and clay objects into the pits.

In contrast to Knosssos, only 17 coins were unearthed in different layers of the sanctuary of Demeter in Contrada Petraro at Entella. ${ }^{88}$ The coins date from 420 to 20 BCE and are from different cities. ${ }^{89}$ Frey-Kupper states that it is difficult to reconstruct a link between the coins, layers, and the votive deposits. ${ }^{90} 11$ bronze coins weight between $1.18-7.67 \mathrm{~g}$, and two bronze coins $28.23 \mathrm{~g}$ and $26.58 \mathrm{~g}$. ${ }^{91}$ Three silver coins have a weight of $0.84 \mathrm{~g}, 2.90 \mathrm{~g}$, and $7.67 \mathrm{~g} .{ }^{92}$ The small number of coins indicates that they were accidentally deposited at this site, and for this reason, there is no link between the coins and the layers of the sanctuary. This may be especially the case with bronze coins, but not with the silver coins (for the value of silver, see Table 2). Most of the coins unearthed during the excavations carried out at Argos and Thasos were made of bronze and only a small part was made of silver. ${ }^{93}$ People were more careful with silver coins than with bronze coins. Silver and gold coins were more worth of care than bronze coins. This means that valuable coins were seldom lost or deposited accidentally with votives. The two silver coins deposited at Entella had a value of ca. 1-2 drachmas and may have been deposited intentionally, as their material value was not significantly high.

87 Coldstream 1973, 130-171.

88 Frey-Kupper 2016, 285, table 1.

89 Frey-Kupper 2016, 285, table 1.

90 Frey-Kupper 2016, 285, table 1.

91 FreY-Kupper 2016, 290-292.

92 Frey-Kupper 2016, 290.

93 For Argos, see Grandjean 2016, 56sqq, and for Thasos, see Picard 2016, 65. 


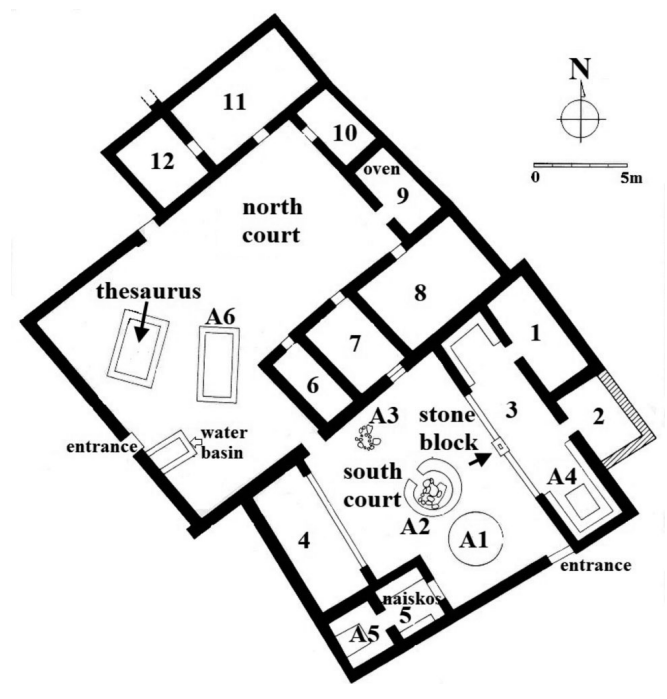

Thesaurus and its use at the sanctuaries of Demeter
Fig. 13. Plan of the central sanctuary of Demeter at Morgantina (Hinz 1998, 132, fig. 28; plan edited by author)

Fees paid by worshippers were conveyed to cultic officials or dropped into stone box called

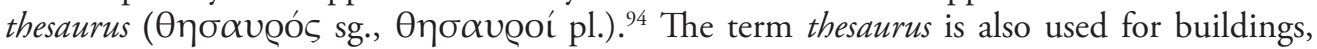
which served as storerooms for valuable votives in sanctuaries. We may compare the thesauroi with boxes in churches nowadays, which are used for the donation of money on a voluntary basis. The thesauroi in antiquity were not only used for the donation of money on a voluntary basis, but also for fees. A thesaurus was unearthed at the central sanctuary of Demeter in Morgantina and three inscriptions dating to the $4^{\text {th }}$ and $1^{\text {st }}$ centuries BCE mention thesauroi situated in the sanctuaries of Demeter at Eleusis ( $I G \mathrm{II}^{2}$ 1672), Andania ( $I G \mathrm{~V}, 1$ 1390), and Cos $(H G K 17)$. Apart from the central sanctuary of Demeter at Morgantina, epigraphic and archaeological evidence for thesauroi is not attested for the sanctuaries of Demeter, where coin hoards were unearthed.

Numerous coins were deposited in two places at the central sanctuary of Demeter in Morgantina: in a rectangular thesaurus ${ }^{95}$ unearthed in situ in the north court and in a stone block in situ in the south court (Fig. 13). The central sanctuary of Demeter in Morgantina is located at the agora. The shrine was founded in the $5^{\text {th }}$ century BCE, and coins were dedicated from the $5^{\text {th }}$ century BCE onwards. ${ }^{96}$ Hinz has suggested that the shrine was initially an open-air sanctuary that consisted of the altars A2 and A3. ${ }^{97}$ In the late $4^{\text {th }}$ or in the early $3^{\text {rd }}$ century BCE, the sanctuary received an architectural elaboration. ${ }^{98}$

94 PAfFord analysed in her unpublished PhD thesis submitted in 2006 at the University of California, Berkeley, the types and the function of stone boxes and their use in Greek sanctuaries. G. Kaminski carried out the most accurate research on different types of thesauroi, their function for different Greek cults, and epigraphic material (1991, 63-181).

95 Thesaurus: Stillwell 1959, 168; Kaminski 1991, 104, 158; Sposito 2008, 226. Stone block: Sposito $2008,226$.

96 Stillwell 1959, 169; SjöQvist, 1964, 141-144; Hinz 1998, 132-134; Sposito 2008, 226, fig. 14-15.

97 Hinz 1998, 132.

98 Hinz 1998, 132. 
Sposito uses the term bothros for the stone block situated in the south court, where coins were deposited. ${ }^{99} \mathrm{~A}$ bothros is a pit dug into the earth and used for sacrifices performed in sanctuaries. The bothros mentioned by Sposito is a bowl-shaped depression cut into a stone block (Fig. 14). I will use the term 'stone block' instead of bothros. The stone block is situated on the threshold of the oikos 3 and has the same width as the wall of the oikos 3 . The stone block was probably part of the oikos 3 that was built in the late $4^{\text {th }}$ or in the early $3^{\text {rd }}$ century BCE..$^{100} 24$ coins found in this stone block date to the $5^{\text {th }}$ and $4^{\text {th }}$ centuries BCE. ${ }^{101}$ The coins were found together with clay votives dating to the $5^{\text {th }}-3^{\text {rd }}$ centuries BCE. ${ }^{102}$ Single coins were also found in different parts of the south court. ${ }^{103}$ The coins consecrated in the $5^{\text {th }}$ century BCE were probably not collected in the stone block, as it dates presumably to the same period as the oikos 3 .

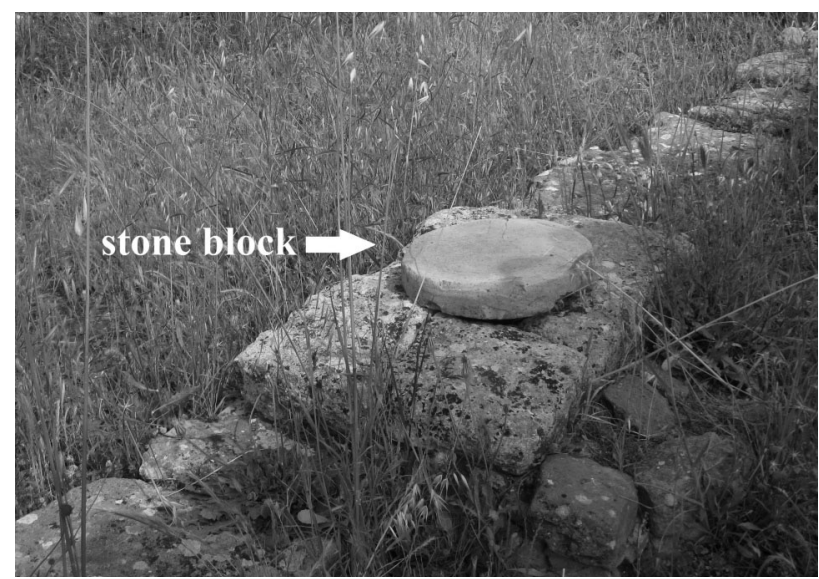

Fig. 14. The stone box located in the south court of the central sanctuary of Demeter at Morgantina (photo by author)

The south court has several altars and an entrance in the south-west. The numerous altars in the south court provide evidence for libation, offerings, and rituals performed at this site. As fees were asks for various offerings and rituals, the coins were deposited into the stone block or collected by cultic officials. At its current state, a circular stone is placed on the stone block (Fig. 14). Coins deposited as fees for rituals into the stone block were retrieved by cultic officials on a daily basis, as the stone block cannot be closed by a locker. Hinz has suggested that the stone block was used for libation. ${ }^{104}$ The recess of the altar at the sanctuary of chthonian deities in Agrigento was also used for libation, and coins with votives were deposited into it at the end of the cult at this site. The stone block at the central sanctuary of Demeter in Morgantina may have been used in the same way. In the $3^{\text {rd }}$ century BCE, coins from two centuries, which were not used as income for the running cost of the shrine, were deposited into the stone block when the thesaurus in the north court came into use. The same practice was also applied to the coins consecrated in the $3^{\text {rd }}$ and $2^{\text {nd }}$ centuries BCE, which were deposited into the thesaurus (Fig. 15).

99 Sposito 2008, 231, fig. 26.

100 Hinz 1998, 132.

101 Buttrey, Erim, Groves, Holloway 1989, 156-157, 186, nos. 4, 8, 53.

102 Sposito 2008, 226.

103 Buttrey, Erim, Groves, Holloway 1989, 186, nos. 51, 54.

104 Hinz 1998, 133. 

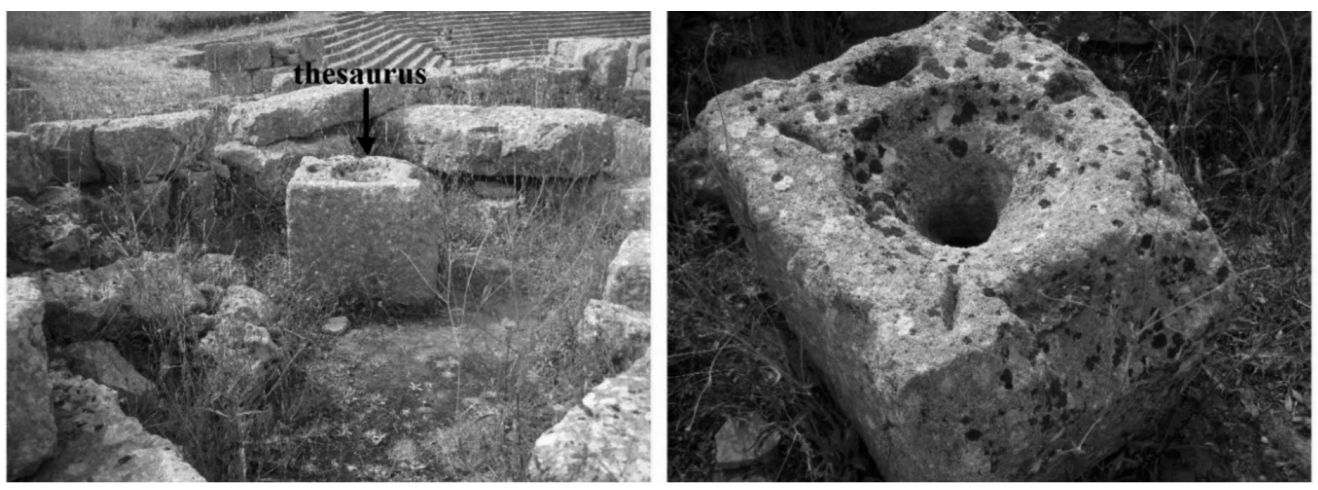

Fig. 15. The thesaurus at its current state situated at the central sanctuary of Demeter in Morgantina (photo by author)

The thesaurus in the north court is situated in an open-air enclosure next to the altar A6 and in proximity to the entrance. It is interesting to note that the stone block and the thesaurus are situated not far from the entrances. Such a location is not unusual for thesauroi found at various sanctuaries. Kaminski has suggested that a wall was built in the $2^{\text {nd }}$ century BCE that surrounded the thesarurus and formed an open-air enclosure. ${ }^{105}$ There is no clear evidence that the open-air enclosure was built in the $2^{\text {nd }}$ century BCE, and not in the $3^{\text {rd }}$ century BCE.

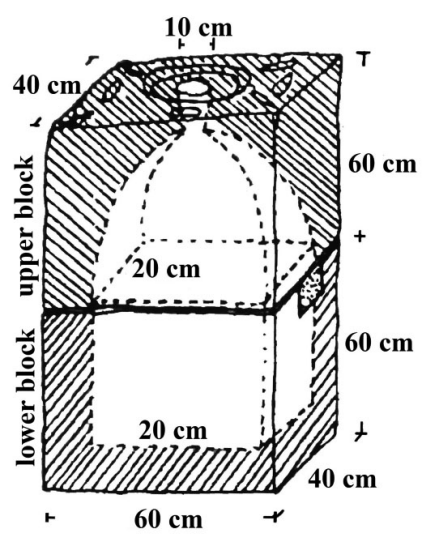

Fig. 16. Drawing of the thesaurus from the central sanctuary of Demeter at Morgantina (KAMINSKI 1991, 158, fig. 25; drawing edited by author) The thesaurus dates presumably to the $3^{\text {rd }}$ century BCE. The open-air enclosure has the same orientation as the thesaurus and aimed to create a separate space for the thesaurus. The open-air enclosure has an entrance in the east and offers a space for up to 2-3 people. At its current state, the wall of the open-air enclosure is low (Fig. 15). The wall was probably high and secured the privacy. The open-air enclosure offered a space that ritualised the consecration of coins into the thesaurus.

The thesaurus has two stone blocks. Each block measures $60 \mathrm{x} 40 \mathrm{~cm}$ and is $60 \mathrm{~cm}$ high. ${ }^{106}$ The upper stone block has a hole $(10 \mathrm{~cm})$ in the middle (Fig. 15). A rectangular bowl (20 x $20 \mathrm{~cm}$ ) is cut into the lower stone block. ${ }^{107}$ Coins dropped into the hole of the upper block were collected in the bowl of the lower block (Fig. 16). The lower block was placed into a pit that had the same depth as the lower block. The upper block was pushed to one side in order to open the thesaurus. To protect the money deposited into the thesauroi, the stone boxes had sophisticated lockers. The thesaurus and the stone 
block situated at the central sanctuary of Demeter in Morgantina can be opened easily by everyone, as they do not have lockers. The money deposited into the thesaurus was presumably retrieved on a regular basis or guardians protected the sacral and public buildings at the agora.

154 bronze coins found in the thesaurus date to the $3^{\text {rd }}-2^{\text {nd }}$ centuries BCE. ${ }^{108}$ Single coins were also found on the altar A6. The single coins found at the south and north courts were dropped accidentally. The coin hoard deposited into the thesaurus includes $3^{\text {rd }}$ century BCE coins from Syracuse, Aetna, Mamertines, Agrigento, and $2^{\text {nd }}$ century coins from Catana ${ }^{109}$ and Roman asses. ${ }^{110}$ According to Buttrey, Erim, Groves, and Holloway, the coins were not collected over a period in the thesaurus, but "scattered down all through the earth filling and formed no chronological pattern". ${ }^{111}$ The soil at this shrine is hard and does not have earth fillings. Buttrey, Erim, Groves, and Holloway assume that the coins might have been deposited into the thesaurus during the period of wars in 139-131 BCE or in 104-101 BCE, and were not retrieved after the end of wars. ${ }^{12}$ If coins deposited into the earth filling were collected and deposited into the thesaurus during the First or Second Servile Wars (135-132 and 104-101 BCE), a distinction between the coins was not made in a period of danger. It is easier for thieves or invaders to find the coins in the thesaurus and in the stone block than in earth fillings. The coins from the stone block date to the $5^{\text {th }}-4^{\text {th }}$ centuries $\mathrm{BCE}$, whereas those from the thesaurus date to the $3^{\text {rd }}-2^{\text {nd }}$ centuries BCE. Another point is that the bronze coins found at this site did not have a high material and monetary value. The material value of all bronze coins found at this site had probably a value of less than 3 drachmas. As coins were demonetized after a period, the bronze coins consecrated in the $5^{\text {th }}-3^{\text {rd }}$ centuries BCE were not used as legal tender in the $2^{\text {nd }}$ century BCE. A small part of coins consecrated by worshippers from the $5^{\text {th }}$ to $2^{\text {nd }}$ centuries BCE were deposited as votives by cultic officials. Low value coins were also selected for this purpose at many other sanctuaries. Coins were not deposited as votives after the $2^{\text {nd }}$ century BCE. The end of the custom of depositing coins was not the end of payment of coins as fees at rituals performed in the sanctuary of Demeter at Morgantina. Stillwell states that the altar and the open-air enclosure with the thesaurus were filled with earth, lamps, bowls, and coins. ${ }^{113}$ The open-air enclosure was probably filled with earth when the sanctuary was abandoned in the $1^{\text {st }}$ century BCE.

The inscription $H G K 17$ ( $4^{\text {th }}$ century BCE) regulated the sale of the priesthood

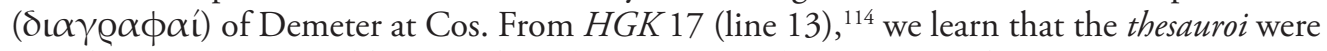
used for the collection of fees paid for cultic services at the sanctuary of Demeter in Cos. ${ }^{115}$ The inscriptions, which concern the thesauroi of various cults on Cos, were dedicated ca. 200 years after $H G K 17$. The inscriptions on thesauroi mentioned in this paper date from the $4^{\text {th }}$ to $1^{\text {st }}$

108 Stillwell 1959, 168; Buttrey, Erim, Groves, Holloway 1989, 172-173, no 43; Kaminski 1991, 104, 158. 109 According to Buttrey, Erim, Groves, and Holloway, the coins from Catana date to the 2nd century BCE $(1989,38)$.

110 STILLWELl 1959, 168.

111 Buttrey, Erim, Groves, Holloway 1989, 174.

112 Buttrey, Erim, Groves, Holloway 1989, 174.

113 STILLWELL 1959, 168.

114 Related lemmata: LSCG 175 and IG XII,4 1:356.

115 The archaeological and epigraphic sources on Demeter from Cos provide evidence for the cult of Demeter from the $6^{\text {th }}$ century BCE to the 1 st century CE (Herzog 1901, 134-135; Kabus-Preisshofen 1975, 31-32, 35; KantZia 1988, 179-181). 
centuries BCE, indicating that the thesauroi were in use at some sanctuaries on Cos from the $4^{\text {th }}$ century BCE onwards. The thesauroi at the sanctuary of Demeter in Cos were probably still in use in the $2^{\text {nd }}$ and $1^{\text {st }}$ centuries BCE. The excavations carried out at the sanctuary of Demeter in Cos did not unearth thesauroi and coins. HGK 17 mentions thesaurus in plural. The amount of money dropped into the thesauro $i$ was apparently significantly high, as several stone boxes were needed. Several inscriptions from Cos dedicated to various deities order the opening of the thesauroi once or twice a year. ${ }^{116}$ The thesauroi at the sanctuary of Demeter were presumably opened once or twice a year.

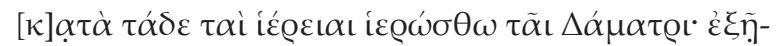

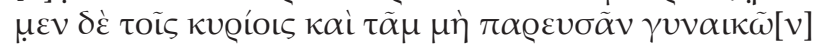

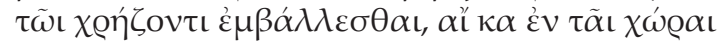

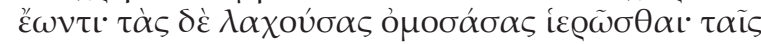

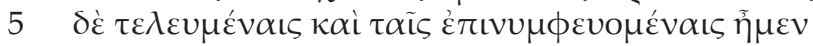

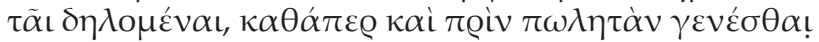

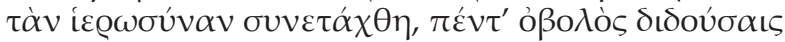

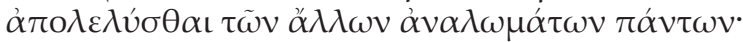

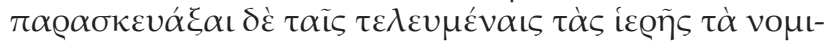

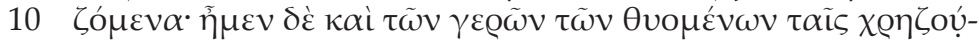

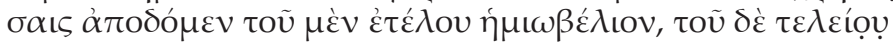

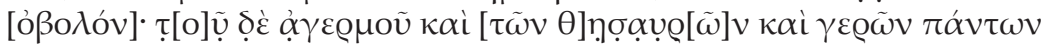

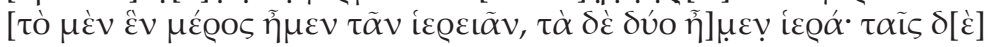

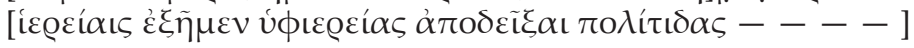

$H G K 17$

According to the following, the priestesses shall hold the priestly office for Demeter. The legal representatives of the women not present too can take part in the ballot, if they are in the country, anybody who wants. Those who have been chosen by lot shall swear an oath before being consecrated as priestesses. Women initiated and about to get married (?) may, if they want, as was prescribed before the priesthood became open for purchase, give five obols in order to be freed from all expenses. The priestesses shall provide the initiates with what is the custom. The women who want to may give by way of gera for the sacrifices half an obol for a young victim, for a full-grown victim an obol. Out of the collection and the theasure-boxes and all the shares [a third belongs to the priestess, two thirds] are sacred. The (priestesses have the right to appoint female citizens as substitute-priestesses

$H G K 17$; translation by Dignas 2004, 262-263.

HGK 17 (lines 10-12) mentions that the worshippers must give a half obol for a young and one obol for an adult sacrificial animal as gera $(\gamma \dot{\varepsilon} \mathrm{Q} \alpha \varsigma)$ that was the honorific share of the priest. The priest was usually allowed to receive one part of the sacrificed animals as his priestly share. The priestess of Demeter at Cos received money or one part of the sacrificed

116 SEG 50:766 ( $2^{\text {nd }}$ century BCE) concerns the cult of Aphrodite Pontia on Cos and mentions that the prostates who were in charge of the keys of the thesauroi should open once a year the thesauroi in the presence of the priestess (lines 16-17). Iscr. di Cos ED 58 ( $2^{\text {nd }}$ century BCE) orders the opening of the thesaurus twice a year (lines 7-8). SEG 51:1066 ( $1^{\text {st }}$ century BCE) indicates that the thesaurus should be opened once a year (line 22). Iscr. di Cos ED 58 and SEG 51:1066 concern the cult of Asclepius on Cos. Iscr. di Cos ED 89 ( $1^{\text {st }}$ century BCE) concerns the cult of Nike on Cos and orders the opening of the thesaurus twice a year (lines 21-23). 
animals. The money paid as gera was dropped into the thesauroi. The monetarization of the gera is attested by epigraphic sources for several cults on Cos: Asclepius: SEG 51:1066, lines 5-15 ( $1^{\text {st }}$ century BCE); Iscr. di Cos ED 58, lines 4-10 ( $2^{\text {nd }}$ century BCE); Iscr. di Cos ED 92, ${ }^{117}$ line 7 ( $3^{\text {rd }}$ century BCE). Nike: Iscr. di Cos ED 89, lines 18-24 ( $1^{\text {st }}$ century BCE). Aphrodite: SEG 50:766, lines 9-10 ( $2^{\text {nd }}$ century BCE). The cults of other deities on Cos mentioned in this paper asked three and six times more fees for sacrificial animals than the cult of Demeter. SEG 50:766 mentions that the soldiers of big warships should sacrifice an animal at a cost of 15 drachmas or give 15 drachmas to the priestess and drop one drachma into the thesaurus (lines 6-9). The worshippers who wanted to sacrifice should pay 2 drachmas as fee for a cow, 1 drachma for an adult animal, 3 obols for a young animal, and 1 obol for a bird (SEG 50:766, lines 10-13). Iscr. di Cos ED $89^{118}$ (lines 18-24) orders the payment of one drachma for a cow and 3 obols for other sacrificial animals. SEG 51:1066 ${ }^{119}$ (lines 5-25) orders that the priest shall receive the skin and the shank of the sacrificed animals, and the worshippers should drop into the thesaurus 2 drachmas for a sacrificed cow, 3 obols for an adult sacrificial animal, and a half obol for a bird. Iscr. di $\operatorname{Cos} E D 58^{120}$ (lines 4-10) has a similar regulation. The sacred laws of the cults of Nike, Aphrodite, and Asclepius order the consecration of money at animal sacrifices that should be dropped into the thesauroi. An inscribed thesaurus $(73 \mathrm{~cm}$ high, 51 $\mathrm{cm}$ in diameter) dating to the $2^{\text {nd }}$ century BCE and dedicated to the local hero Theagenes was found at the agora of Thasos town. ${ }^{121}$ LSS 72 (lines 1-3) engraved on the thesaurus mentions that the worshippers who wanted to sacrifice to Theagenes should drop not less than one obol into the thesaurus. ${ }^{122}$ LSS 72 (lines 2-3) uses the verb $\alpha \pi \alpha$ $\alpha \chi \varepsilon \sigma \theta \alpha \mathrm{L}$ (aparchestai) for the payment of the fee at sacrifice. ${ }^{123}$ An inscription $(230 \mathrm{BCE})$ from Olbia also orders the payment

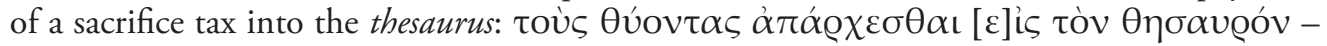
those performing sacrifice should make a first fruit offering ( $\alpha \pi \alpha ́ \alpha \chi \varepsilon \sigma \theta \alpha \mathrm{l})$ into the thesaurus (IGDOlbia 88, lines 11-12). The same expression is also used in LSS 72 (lines 1-3). Initially, the term aparche refers to First-fruit offering made in kind. The two inscriptions refer to coins inserted into the thesauroi as fees at every sacrifice. Apart from SEG 50:766 (lines 10-11), the inscriptions from Cos mentioned in this paper do not use the term aparchestai for the payment of sacrifice tax. Therefore, the fees ordered in these inscriptions were also fees paid at every sacrifice. The fee asked as a preliminary ritual at every sacrifice was between a half obol and several drachmas. As Sokolowski illustrates, cultic services offered at sanctuaries preceded or followed by sacrifices, ${ }^{124}$ suggesting that sacrifices were frequently performed. Depending on the size of the sacrificial animal, a half, one, two, or three obols were imposed as a fee for animal sacrifice. ${ }^{125}$ Pafford has suggested that the dedication of coins at every sacrifice was a preliminary sacrifice - proteleia - that was "ritually performed through the payment of a spe-

117 Related lemmata: $I G$ XII 4,1, 336.

118 Related lemmata: $L S C G$ 163; IG XII 4,1, 330.

119 Related lemmata: $I G$ XII 4,1, 294.

120 Related lemmata: $L S C G$ 164; IG XII 4,1, 342.

121 According to Pausanias 6.11.9, Theagenes was worshipped as a hero with healing powers.

122 LSS 72 is discussed in detail by MARTIN 1940, 175-183.

123 See also SoKoLowsKi 1962, 133

124 SокоLOwsKi 1954, 153sqq.

125 MarTin 1940, 181-181. 
cific denomination of coin". ${ }^{126}$ The proteleia was a preliminary offering made to a deity before marriage. ${ }^{127}$ Before a sacrifice was performed at a sanctuary, the ordered sum was dropped into the thesaurus as preliminary ritual.

$H G K 17$ mentions that one-third of the money from the thesauroi belongs to the priestess and two-third to the sanctuary. Sacred laws of different sanctuaries on Cos had similar regulations concerning the income from the thesauroi. ${ }^{128}$ IGDOlbia 88 (lines 6-9) mentions that the thesaurus was opened once a year and the money was entrusted to the hieromnemon who took it in custody until 1000 drachmas came together. ${ }^{129}$ Priests and officials of the city oversaw the administration of the money from the thesauroi. The income from the fees asked at animal sacrifices were considerable for the sanctuary of Asclepius at Cos that had Pan-Hellenic significance. Demeter had a small sanctuary at Cos and she did not have the same significance as Asclepius for Cos. If we assume that a half obol was consecrated for a young and one obol for an adult sacrificial animal ( $H G K 17$, lines 10-12), the income from the thesauro $i$ was probably less than 1000 drachmas. It seems unlikely that 6,000 and more animals were sacrificed each year to Demeter at Cos. ${ }^{130}$

Iscr. di $\operatorname{Cos} E D 14\left(3^{\text {rd }} / 2^{\text {nd }}\right.$ century BCE $)$ from Cos is partially preserved. The inscription is a subscription list that lists the names of women who are announced to the sanctuary of Demeter. For the funding of public and sacral buildings or festivals, ${ }^{131}$ the polis called for subscriptions,

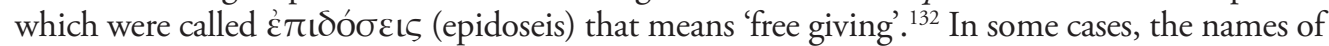
the benefactors were listed on a stele. The subscriptions offered wealthy families to display their social status, piety, and wealth. Iscr. di Cos ED 14 honours the benefactors who contributed a high sum to the sanctuary of Demeter at Cos. The preserved 23 lines of Iscr. di Cos ED 14 list partially the names of 42 women. The name of the father is mentioned after the name of the female benefactors. Migeotte has suggested that the whole stele listed the names of 88-100 women who donated money for the construction of a building, restoration, or for the maintenance of the sanctuary of Demeter at Cos. ${ }^{133} S E G 43: 212 \mathrm{~A}\left(3^{\text {rd }-} 2^{\text {nd }}\right.$ century BCE) reveals that women were invited to donate money for the new sanctuary of Demeter at Tanagra (see also LSCG 72). At Cos too, only women were invited to donate money for the sanctuary of Demeter. The sanctuary of Demeter at Cos had an oikos $\left(24 \times 6 \mathrm{~m}\right.$ ) with a water basin. ${ }^{134}$ It may be that this oikos was financed with the money donated by women listed in Iscr. di Cos ED 14. An amount between 100 and 500 drachmas is mentioned behind the names of 31 women listed in this inscription. A law $\left(2^{\text {nd }}\right.$ century BCE) from Teos regulating the education of children determines $600-500$

\section{PAFFord 2013, 50.}

127 An inscription on a thesaurus dedicated to Aphrodite Ourania orders one drachma as proteleia at marriage (SEG 41:182, early $4^{\text {th }}$ century BCE).

128 The priestess should receive the half of the income from the thesauroi and Aphrodite the other half (SEG 50:766; lines 17-20). The money Aphrodite received from the thesauroi should be used for the maintenance of the sanctuary (SEG 50:766, lines 21-22). Iscr. di Cos ED 89 also orders that the priest should receive the half of the income from the thesaurus and Nike the other half (lines 20-21).

129 See also Martin 1940, 186; Picard 1990, 315, 321; PAfFord 2013, 50sq.

1301,000 drachmas as sacrifice fees make up 6,000 animals if one obol was paid at every animal sacrifice.

131 For the cost of festivals, see also $I G \mathrm{II}^{2} 1635$ (lines 35-37) and $I G \mathrm{I}^{3} 258$ (lines 4-10).

132 For subscription, see Migeotte 1992; Ellis-Evans 2013, 107-108; Gygax 2016, 19-26. Migeotte collected epigraphic sources on subscription and made an accurate analysis (1992).

133 Migeotte 1998, 571.

134 Kantzia 1988, 179. 
drachmas as annual wage of teachers (CIG 3059, lines 11-13). The salary of teachers mentioned in $C I G 3059$ demonstrates that the sum of 100-500 drachmas was very high. Only people with a high income were able to donate 100-500 drachmas. The total amount of money mentioned after the names of 31 women makes up 9,300 drachmas. If we assume that the 11 women, whose names or the sum are not visible, donated at least 100 drachmas, the total amount listed behind the names of 42 women was more than 10,400 drachmas. If the women, who were listed on the missing part of the stele, also donated at least 10,400 drachmas, the total amount of money donated by ca. 84 women was at least 20,800 drachmas. The money was not collected in thesauroi, but by the priestess of Demeter or by civic officials of the polis. It seems more likely that the thesauroi in the sanctuary of Demeter at Cos were only used for sacrifice fees, as indicated in $H G K 17$, and for other fees asked at rituals performed by single worshippers.

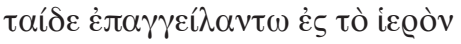

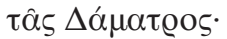

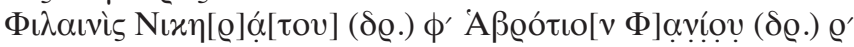

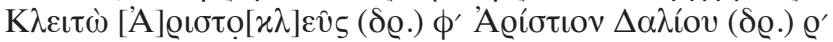

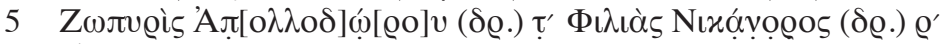

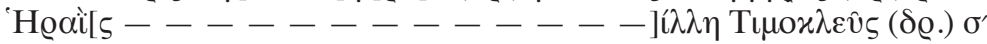

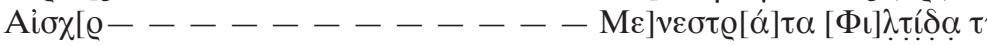

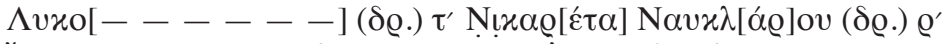

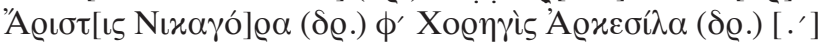

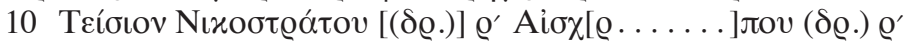

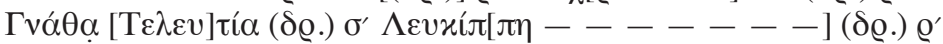

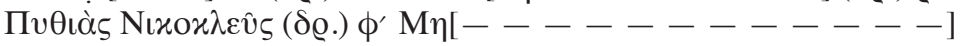

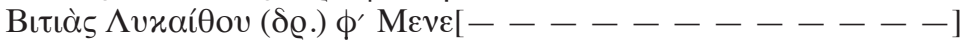

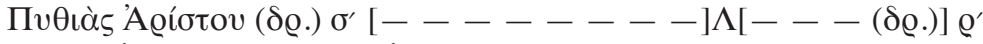

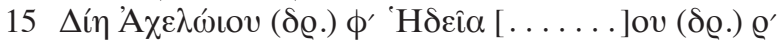

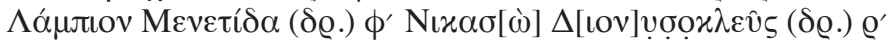

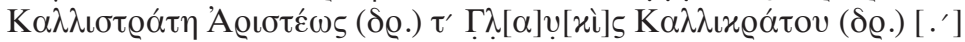

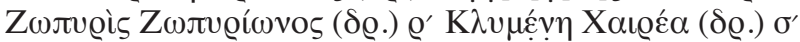

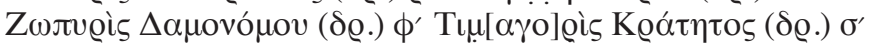

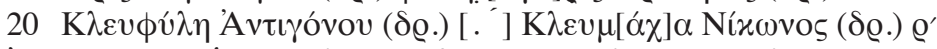

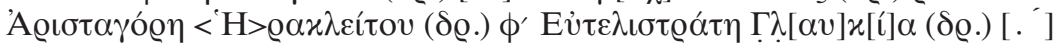

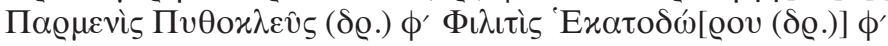

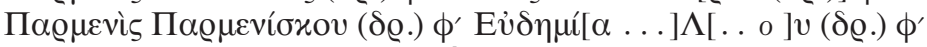

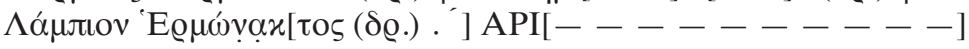

$25[----------------]$

Iscr. di Cos ED 14

Announce them to the sanctuary of Demeter.

Philainis, the daughter of Nikeratos (500 dr.), Habrotion, the daughter of Phanios

(100 dr.)

Kleito, the daughter of Aristokleos (500 dr.), Aristion, the daughter of Dalios (100 dr.)

5 Zopyris, the daughter of Apollodoros (300 dr.), Philias, Nikanoros (100 dr.),

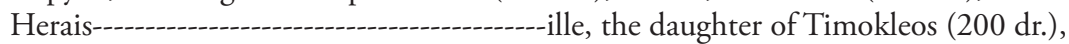

Aischr Menestrata Philtida (300 dr.),

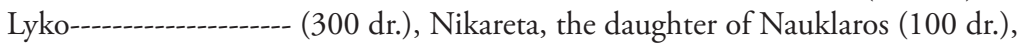

Aristis Nikagora (500 dr.), Choregis Arkesila (dr.), 
10 Teision, the daughterNikostratos (100 dr.), Aischr---, the daughter of -----pos (100 dr.),

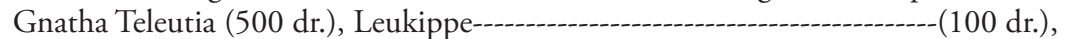
Pythias, the daughter of Nikokleos (500 dr.), MeBitias, the daughter of Lykaithos (500 dr.), MenePythias, the daughter of Aristos (200 dr.),

15 Die, the daughter of Acheloios (500 dr.), Hedeia, the daughter of -----------os (100 dr.), Lampion Menetida (500 dr.), Nikaso, the daughter of Dionysokleos (100 dr.), Kallistrate, the daughter of Aristos, (300 dr.), Glaukis, the daughter of Kallikratos (dr.), Zopyris, the daughter of Damonomos (500 dr.), Timagoris, the daughter of Kratetos (200 dr.),

Kleuphyle, the daughter of Antigonos (dr.), Kleumacha, the daughter of Nikonos (100 dr.),

20 Aristagore, the daughter of Herakleitos (500 dr.), Eutelistrate Glaukia (dr.), Parmenis, the daughter of Pythokleos (500 dr.), Philitis, the daughter of Hekatodoros (500 dr.),

Parmenis, the daughter of Parmeniskos (500 dr.), Eudemila, the daugther of ---(500 dr.),

Lampion, the daughter of Hermonaktos (dr.), Ari

Another inscription providing evidence for thesauroi is from Andania that dates to $92 \mathrm{BCE}$ and concerns the mysteries of Demeter and Persephone ( $I G \mathrm{~V}, 1$ 1390). The sacred law orders two thesauroi (IGV,1 1390, lines 90-95): one thesaurus should be placed in the temple and the second at the fountain. The thesauroi were locked by keys. Mnasistratos, a priest of Demeter and Persephone, and sacred men were in charge of the keys of the thesaurus near the fountain. The thesauro $i$ were opened once a year to the mysteries, and the money from each box was counted separately. Mnasistratos received one-third of the money collected in the thesauros at the fountain. The inscription does not tell us whether the fees for the mysteries were collected in the thesauroi and the money from thesauroi was used for the performance of the mysteries. As the sacred law $I G \mathrm{~V}, 11390$ concerns the regulation of the mysteries and the thesauroi were only opened at the mysteries, the money from the thesauroi was presumably used for the mysteries. Such festivals were well organised, the cost was calculated in advance, sacrificial animals were bought before the beginning of the festival, and wages for different services and organisation were paid. If the money collected in thesauroi covered one part of the cost of the mysteries, a regular average income from the thesauroi was necessary for the planning.

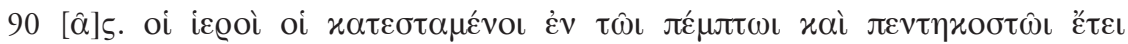

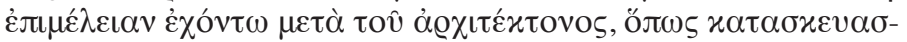

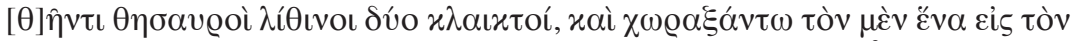

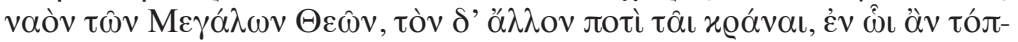

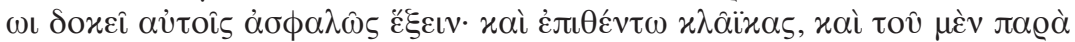

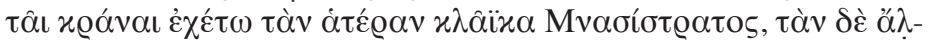

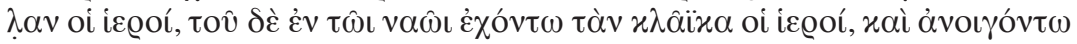

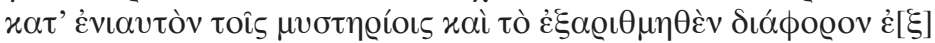

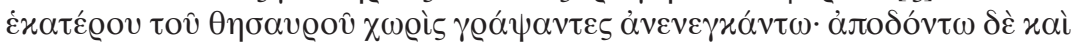

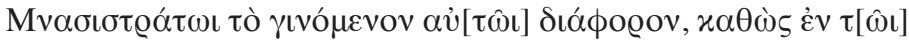

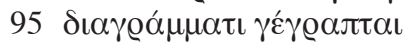


90 The sacred men appointed in the fifty-fifth year, along with the director of building, are to be careful that two stone treasuroi, that can be closed, are prepared; they are to place one in the temple of the Great Gods and the other near the fountain at whatever place seems to them to be safe. They are to provide keys: for the treasuros by the fountain, Mnasistratos is to have one key and the sacred men the other; for the treasury in the temple the sacred men are to have the key; and they are to open them every year for the mysteries. They are to bring forth and record the money, which is to be counted out from each treasury separately; they also are to give Mnasistratos the money coming to him,

95 as it is written in the rule. "

$I G \mathrm{~V}, 1$ 1390; translation by Meyer 1987, 57.

\section{Commercialized salvation and the First-fruit offerings}

Hymns were sung at festivals and symposiums and were very popular during the $7^{\text {th }}$ and $6^{\text {th }}$ centuries BCE. ${ }^{135}$ In the late $6^{\text {th }}$ century BCE under the Athenian rule, the Homeric Hymn to Demeter composed around the $7^{\text {th }}$ and $6^{\text {th }}$ centuries BCE was transcribed from the oral tradition. The reason why Athens took an interest in cultic activities at Eleusis, beginning with Solon, is linked to the conflicts with the Doric city Megara that was in dispute with Athens over Eleusis, an Ionian city like Athens. Athens pretended that the Doric city Megara occupied the Ionian city Eleusis and claimed priority over the Eleusinian cult.

It is during this period that the image of the netherworld began to change from being simply a dark and unhappy place, as recorded in Homer's Odyssey (10.491-494, 509, 564; $11.47,226,385)$. Homeric idea of the soul after death gave way to a new view of the soul as an immortal being worthy of a better afterlife. The soteriological aspect of the cult of Demeter and Persephone was enforced in the hope for a better afterlife. The Homeric Hymn to Demeter (480-483) mentions that Demeter gave the order and instruction for the performance of her mysteries that promised a better afterlife for those who were initiated into her mysteries. However, whoever was not initiated into the sacred rites of Demeter had to dwell in the gloomy realm of the underworld. The Homeric Hymn to Demeter offers salvation and the option for mortals to escape the dark realm described by Homer (Il. 8.13-16; Od. 10.542, 590) and Hesiod (Theog. 841) without explaining what else exists in the afterlife apart from the gloomy darkness.

In the $6^{\text {th }}$ century BCE, Athens' main aim was to justify its territorial claims concerning Eleusis towards Megara. For this reason, Athens was integrated into the Eleusinian Mysteries in order to emphasize the significance of Athens for the Eleusinian Mysteries. The Eleusinian Mysteries had local significance in the $6^{\text {th }}$ century BCE. The political changes after the Persian Wars brought new objectives. The objective of Athens as leader of the new Delian League was to promote the Eleusinian Mysteries to Pan-Hellenic mysteries under the religious leadership of Athens. Awareness of the significance of the Eleusinian Mysteries was also increased through heralds dispatched through the Greek world to invite people to the mysteries. Sokolowski makes a good point in saying that "we should note in conclusion that the rules regulating the 
celebration of the Eleusinian Mysteries were drawn up and issued not at one time but grew slowly as the current customs and popular need dictated" by Athens. ${ }^{136}$

The chance to prepare for a better afterlife had its price. Athenaeus (2.12) says that telete means to spend, as the organisation and the performance of the mysteries entail costs. The term $\tau \varepsilon \lambda \varepsilon \tilde{\imath} \nu$ (telein) means 'to accomplish' and 'to perform', and $\tau \varepsilon \lambda \varepsilon \tau \eta$ (telete) means 'rite'. Both terms are closely linked to the mystery rites. ${ }^{137}$ The organisation and performance of the Eleusinian Mysteries were a costly matter for the sanctuary and for initiates who paid high fees for the initiation into the Eleusinian Mysteries.

And we call those festivals which are of greater of greater magnitude and which are celebrated with certain mysterious tradition, $\tau \varepsilon \lambda \varepsilon \tau \alpha \grave{i}$, on account of the expense which is lavished on them. For the word $\tau \varepsilon \lambda \varepsilon \tilde{\imath} v$ means to spend.

Athenaeus 2.12; translation by Yonge $1854 .{ }^{138}$

The Eleusinian Mysteries are referred to as Lesser and Great Mysteries performed at the sanctuary of Demeter in Eleusis. The Lesser Mysteries were the first state of the initiation and took place in the month of Anthesterion ${ }^{139}$ ( $I G \mathrm{I}^{3}$ 6b, lines 36-43; Plutarch, Demetrius 26.1). The Greater Mysteries, the most significant mysteries in ancient Greece, were performed in the month of Boedromion (Plutarch, Demetrius 26.1-2). The Eleusinian Mysteries lasted ten days and began with a procession from Athens to Eleusis. We can assume that the fees were also paid in the $6^{\text {th }}$ century BCE for the initiation into the Eleusinian Mysteries and the payment was probably made in kind or ingots used as pre-monetary currency. With the acceleration of the monetarization of the markets in the $5^{\text {th }}$ century BCE, the payment was replaced by coins. $I G \mathrm{I}^{3} 6$ is a decree from Athens dating to $460 \mathrm{BCE}$ that was inscribed on four sides of a stele. ${ }^{140}$ The decree disposed on side $\mathrm{C}$ regulates the Eleusinian Mysteries and the fees paid to cultic officials. The exact fees for the Eleusinian Mysteries are unknown. IG II $^{2} 1672$ (line 207) dating to $329 \mathrm{BCE}$ mentions that the fees for the initiation of two slaves into the Eleusinian Mystereies were 30 drachmas, suggesting that each slave paid 15 drachmas. Free people had to pay at least the same fees. We do not have epigraphic evidence for the number of people who were initiated each year. The Telesterion, where the mysteries were performed, offered the place for up to 3,000 people. Approximately 2,000-3,000 people may have been initiated each year into the Eleusinian Mysteries. ${ }^{141}$ By paying 15 drachmas each in fees, the 3,000 initiates brought in 45,000 drachmas a year (7,5 talent). It is, therefore, not recorded whether the 15 drachmas also covered the fees for sacrifices and the fees paid to cultic officials, as ordered in $I G \mathrm{I}^{3}$ 6c (lines 5-38).

The fees of 15 drachmas for the initiation into the Eleusinian Mysteries were significantly high $\left(I G \mathrm{II}^{2} 1672\right.$, line 207). If we consider that the wages were approximately one drachma a day, 15 drachmas were the wages of two weeks. We should also add to these fees the costs

136 SокоLоwsкi 1959, 5-6.

137 SсHuddeboom analysed the terms linked to mysteries, and the meaning of the terms telein and telete (2009, 7 sqq).

138 Yonge, C.D. 1854. The Deipnosophists or Banquet of the Learned of Athenaeus (London: Henry G. Bohn)

139 Anthesterion fells in February/March.

140 For $I G \mathrm{I}^{3}$ 6, see also Davies 2001, 120.

141 Dowden 1980, 425. 
for accommodation, food, and the trip to Eleusis. Not only people from Attica attended the Eleusinian Mysteries, but also people from different regions in the Greek world. The income from the Eleusinian Mysteries was considerable for the sanctuary of Demeter at Eleusis and for the two cities - Athens and Eleusis - involved in the performance of the mysteries. Not only the sanctuary and the cultic officials at Eleusis were the beneficiaries of the Eleusinian Mysteries but also the local people who sold food and offered accommodation. It is not recorded whether the participants had to pay the fees for the Eleusinian Mysteries at Athens or at Eleusis. As the procession began in Athens, the fees were probably paid in Athens.

$[\ldots \ldots \ldots . . \ldots \mathrm{o} \beta \mathrm{o} \lambda[\ldots]$

[....... ]о : hı

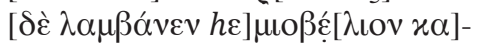

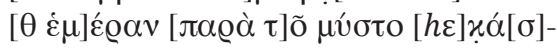

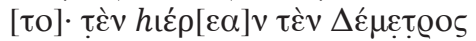

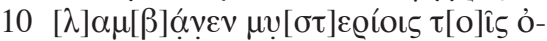

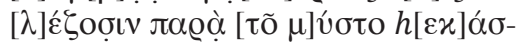

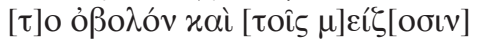

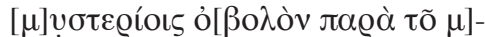

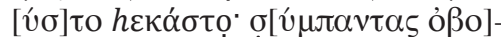

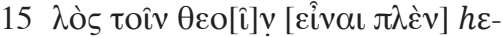

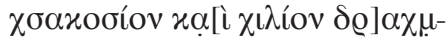

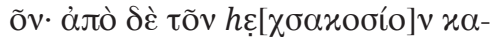

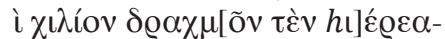

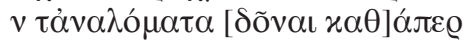

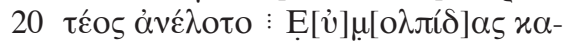

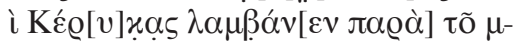

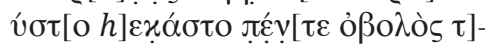

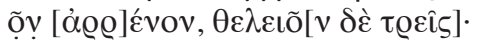

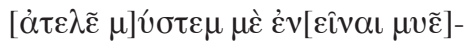

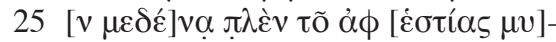

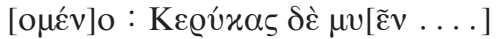

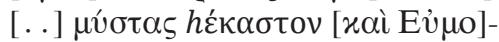
$[\lambda \pi i \delta] \alpha \varsigma[\chi] \alpha \tau \hat{\alpha} \tau \alpha[\hat{v}] \tau \alpha \dot{\varepsilon} \cdot \dot{\varepsilon}[\ldots .$.

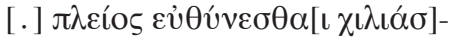

30 [ı] $\delta \varrho \alpha[\chi] \mu \tilde{\varepsilon} \sigma \iota \cdot \mu v \tilde{\varepsilon} v \delta \dot{\varepsilon} h[$ [ò̀ $\grave{\alpha} v h \varepsilon \beta]-$

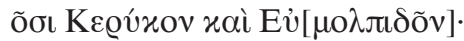

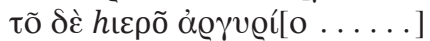

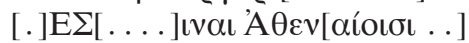

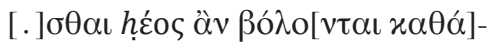

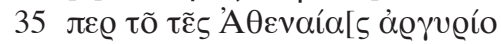

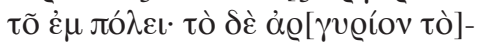

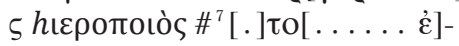

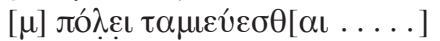

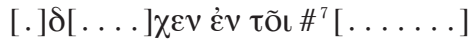

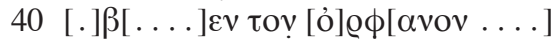

... an obol from each [initiate]; and the (two) shall take half an obol each from each initiate; and the priestess of Demeter shall take at the Lesser Mysteries from each initiate an obol, and at the Greater Mysteries an obol from each initiate; all the obols shall belong to the two Goddesses except for 1,600 drachmas; and from the 1,600 drachmas the priestess shall pay the expenses just as they have been paid until now and the Eumolpidai and the Kerykes are to take from each initiate 5 obols from the men, 3 obols from the women;

an initiate who has not paid shall not enter any initiation except for the hearth-initiate; and the Kerykes shall initiate the initiates -, each one, and the Eumolpidai in the same way; but if .

more, they shall be fined

[a thousand] drachmas at their scrutiny; and those of the Kerykes and Eumolpidai who have reached adulthood may initiate; and the Athenians may use the sacred money as they wish, just like the money of Athena on the Acropolis; the hieropoioi shall look after the money on the Acropolis ...

... in the ...

of the orphans ... 


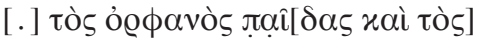

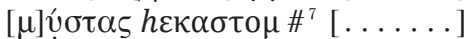

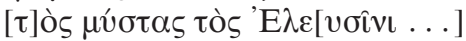

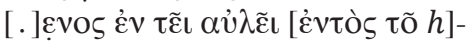

$45[\mathrm{l}] \varepsilon \varrho \tilde{o}, \tau$,ò $\delta \dot{\varepsilon} \dot{\varepsilon} v$ ó $\sigma \tau \varepsilon \iota[\ldots . .$.

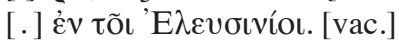

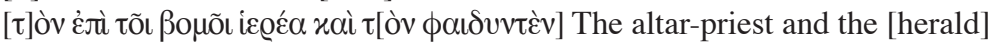

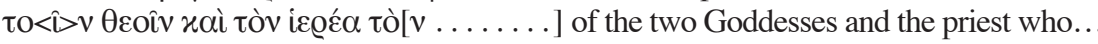

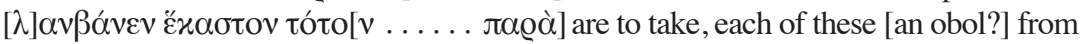

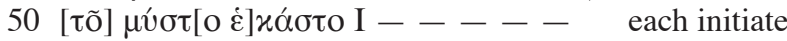

the orphan children and the

initiates each ...

the initiates who are

at Eleusis in the courtyard within the

sanctuary, and those who are in the city

in the Eleusinion.

$I G \mathrm{I}^{3} 6 \mathrm{c}$; translation by Stephen Lambert.

The hierophoioi received a half-obol each day from each initiate ( $I G \mathrm{I}^{3} 6 \mathrm{c}$, lines $\left.5-8\right)$. The hieropoioi were appointed by the city and were in charge of finances, administration, sacrifices, and festivals. ${ }^{142}$ The decree does not precise whether each hieropoios received a half-obol or all hieropoioi together. The hieropoioi appointed by the city received their salary from the city and not from the initiates. ${ }^{143} \mathrm{~A}$ half-obol from each initiate makes by 3,000 initiates 250 drachmas a day. If the initiates had to pay for ten days, the hieropoioi received 2,500 drachmas together at the end of the Eleusinian Mysteries. The priestess of Demeter shall receive at the Lesser and Greater Mysteries one obol from each initiate ( $I G \mathrm{I}^{3} 6 \mathrm{c}$, lines 9-14). By maximum 3,000 initiates at the Lesser and Greater Mysteries, the priestess of Demeter received approximately 1,000 drachmas. The Eumolpidai and the Kerykes shall receive from each male initiate 5 obols and from each female initiate 3 obols $\left(I G \mathrm{I}^{3} 6 \mathrm{c}\right.$, lines 21-23). The Eumolpidai and Kerykes were two families based at Eleusis who were in charge of the organisation of the Eleusinian Mysteries and provided cultic officials, such as the hierophants, torchbearers, and sacred heralds. It is unknown whether most of the initiates were men or women. Supposing $50 \%$ of the initiates were men. The two families received 2,000 drachmas from 3,000 initiates (see Table 3).

A male initiate paid 11 obols as fees during the Eleusinian Mysteries (Table 3): 5 obols to the hieropoioi, 1 obol to the priestess of Demeter, and 5 obols to the Eumolpidai and the Kerykes. 11 obols paid as fees to different cultic officials comprise only $12 \%$ of the total fee of 15 drachmas ( $I G \mathrm{II}^{2} 1672$, line 207) paid for the initiation into the Eleusinian Mysteries. The fees paid to the cultic officials listed in $I G \mathrm{I}^{3} 6 \mathrm{c}$ (lines 5-14, 21-23, 47-50) brought by 3,000 initiates 6,000 drachmas (see Table 3). Supposing that the sum of 6,000 drachmas was paid from the fees for the initiation, 39,000 drachmas remained $(45,000-6,000=39,000)$. It is not recorded which expenses were covered with this money. $I G \mathrm{I}^{3} 386$ (lines 145-146) dating to $407 \mathrm{BCE}$ mentions that the fees for 2,200 initiates at the sanctuary of Demeter in Eleusis brought 4,400 drachmas. 2,200 initiates paid more than 2 drachmas as fees for the initiation into the mysteries. This amount probably remained after payment of expenditure.

The sacred money - income from the fees - had to be deposited on the acropolis of Athens and the city had the right to use it as it wanted $\left(I G \mathrm{I}^{3} 6 \mathrm{c}\right.$, lines 32-35). Such a high income from the fees was considerable for a sanctuary and cultic officials, but not for a city like Athens. It was, therefore, crucial for a city to have a sanctuary that had a Pan-Hellenic significance. 
Table 3. $I G \mathrm{I}^{3} 6 \mathrm{c}$ (460 BCE), a decree from Athens regulating the Eleusinian Mysteries. The income of cultic officials of the sanctuary of Demeter at Eleusis from the Eleusinian Mysteries. The following calculation is hypothetical.

Length of the Eleusinian Mysteries: 10 days (14 to $23^{\text {td }}$ of Boedromion)

Number of people who were initiated each year into the Eleusinian Mysteries: ca 2,000-3,000

For the following calculation, 3,000 initiates are taken into consideration

The hieropoioi shall receive a half obol each day from each initiate (lines 5-8)

5 obols from each initiate (half obol $\times 10=5$ )

1,500 obols a day from 3,000 initiates $\Rightarrow 1500 \times 10=15,000$ obols $\quad \Rightarrow \mathbf{2 , 5 0 0}$ drachmas

The priestess of Demeter shall receive at the Lesser and Greater Mysteries an obol from each initiate (lines 9-14)

$\begin{aligned} 1 \times 3000=3,000 \text { obols } & \Rightarrow 500 \text { drachmas for the Lesser Mysteries } \\ 1 \times 3000=3,000 \text { obols } & \longrightarrow 500 \text { drachmas for the Greater Mysteries } \\ & \longrightarrow \text { ca 1,000 drachmas }\end{aligned}$

The Eumolpidai and the Kerykes shall receive from each male initiate 5 obols and from each female initiate 3 obols (lines 21-23)

assuming that $50 \%$ of the initiates were men and $50 \%$ were women

$5 \times 1500=7500$ obols from men

$3 \times 1500=4500$ obols from women

$7500+4500=12,000$ obols $\quad \rightarrow 2,000$ drachmas

The altar-priest and the [herald?] of the two Goddesses and the priest who ... are to take, each of these [an obol] from each initiate (lines 47-50)

$1 \times 3000=3,000$ obols 500 drachmas

Total income of cultic officials listed above: $2,500+1,000+2,000+500=6,000$ drachmas

Clinton assumes that the treasury of Demeter at Eleusis received all the money listed in $I G$ $\mathrm{I}^{3} 6 \mathrm{c}$ as fees paid to cultic officials, "except for 1,600 obols $^{144}$ to be spent by the priestess on expenses as she had done in the past". ${ }^{145}$ As cultic officials were in charge of different cultic rituals, the fees ordered in $I G \mathrm{I}^{3} 6 \mathrm{c}$ were probably used for such expenses. However, the amount of ca 45,000 drachmas (15 x 3000) is significantly high for a festival. $I G \mathrm{I}^{3}$ 6c (lines 32-35) emphasizes the supremacy of Athens over Eleusis and its cult, but also the high income from the fees paid at the Eleusinian Mysteries. If the Eleusinian cultic officials received all the fees paid at the Eleusinian Mysteries and a small sum was left after expenses, it was not necessary to deposit the money on the acropolis.

Athens enacted several decrees in the $5^{\text {th }}$ and $4^{\text {th }}$ centuries BCE for the regulation of the aparche ( $\dot{\alpha} \pi \alpha \varrho \chi \eta),{ }^{146}$ the so-called First-fruit payment, to Eleusis. The offering of aparche had to ensure the agricultural fertility. The Athenians and the member cities of the Delian League

144 CuInton may have written by mistake 'obols' instead of 'drachmas'. Clinton refers to $I G \mathrm{I}^{3} 6 \mathrm{c}$, lines 14-20.

145 Clinton 1974, 13.

146 Jim analysed in her published PhD thesis the different aspects of aparche in ancient Greece (2014). 
were ordered to pay the aparche to Demeter, who was considered to be the giver of the agricultural gift. The member cities of the Delian League had to send the aparche to Eleusis short after the wheat and barley harvest. Traditionally, the First-fruits were offered to different deities and consisted of a small amount of grain or other perishable food, which were burnt or put on the altar or onto the earth.

$I G \mathrm{I}^{3} 78,{ }^{147}$ the first Athenian decree regulating the aparche to Eleusis, was enacted in 425-422 BCE. ${ }^{148}$ This is the period between the Battle of Phylos in $425 \mathrm{BCE}$ and the Peace of Nicias in 421 BCE. According to $I G \mathrm{I}^{3} 78$ (lines 4-5), the Athenians had to pay the aparche to the two goddesses according to the ancestral traditions and Delphic oracle. The allies - member cities of the Delian League - had to pay the aparche in the same way as Athens $\left(I G \mathrm{I}^{3} 78\right.$, lines 16-17). Another Athenian decree that mentions the payment of aparche is $I G \mathrm{II}^{2} 140$ (353 BCE). The First-fruit offerings have a long tradition going back to earlier periods and were made to local sanctuaries. There is no evidence that the aparche was also paid to Eleusis in earlier periods and the sanctuary of Demeter at Eleusis had a Pan-Hellenistic significance during the Archaic period. Athens did not have the political power in the $6^{\text {th }}$ century BCE to impose the payment of the aparche on Greek cities. The Delian League was established after the Persian Wars in 478 BCE under the leadership of Athens. The Athenian decree justifies the payment of aparche to Eleusis with 'ancestral traditions and Delphic oracle'. $I G \mathrm{I}^{3} 78$ was not the first Athenian decree that imposed the payment of aparche on allies of the Delian League. The Athenian decree $I G \mathrm{I}^{3} 259$ dating to $454 \mathrm{BCE}$ also ordered the payment of aparche - one-sixtieth of the tribute named phoros (申ógos) paid by allies - to Athena. This decree was enacted at the time when the treasury of the Delian League was transferred from Delos to Athens. Such payments to the sanctuary of Athens had to emphasize the political and religious leadership of Athens. With such financial support, the sanctuaries of Demeter and Athena were also able to organize festivals, which exacted high costs. The allies were required by Athenian decrees to pay for its major cults and to send representatives to the major festivals of Athens, such as the Eleusinian Mysteries and the Panathenaia. ${ }^{149}$

$I G \mathrm{II}^{2} 78$ (422 BCE) found on the acropolis of Athens also orders the payment of aparche to Eleusis and gives insight into the finances of the sanctuary of Demeter and Persephone at Eleusis. ${ }^{150}$

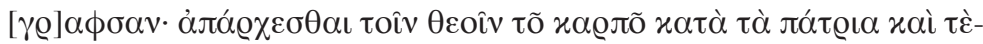

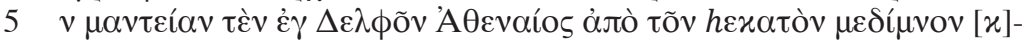

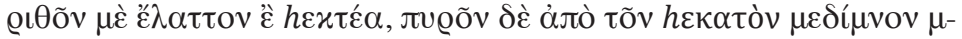

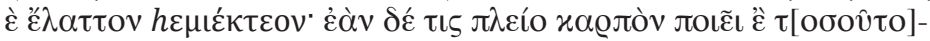

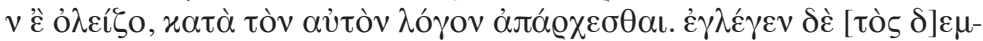

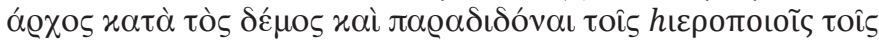

10 'E $\lambda \varepsilon v \sigma ı v o ́ \theta \varepsilon v$ 'E $\lambda \varepsilon v \sigma i ̂ v \alpha ́ \delta \varepsilon$. oix

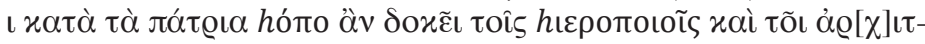

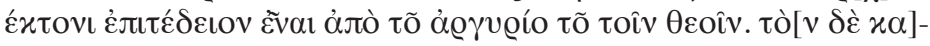

147 The stele with the inscription $I G \mathrm{I}^{3} 78$ was found at Eleusis.

148 For further discussion on $I G \mathrm{I}^{3} 78, I G \mathrm{II}^{2} 1672$ and aparche, see also Cavanaugh 1996, 29sqq; Pazdera 2006, 84-91; Bruit Zaidman 2007, 66sqq.

149 The most significant festival of Athena at Athens was the Panathenaia.

150 Pazdera 2006, 84sqq. 


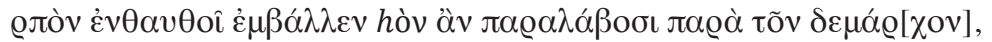

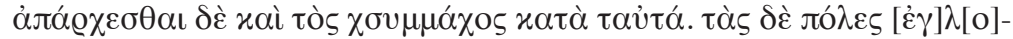

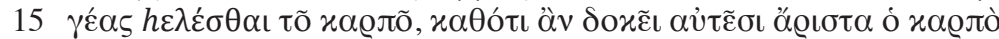

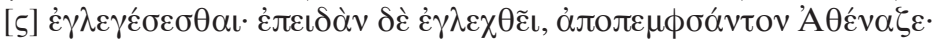

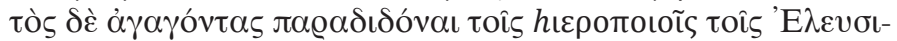

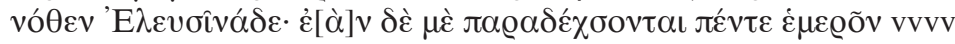

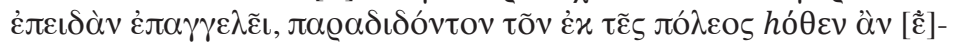

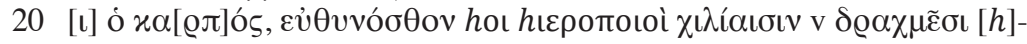
$[\varepsilon ́ x \alpha \sigma] \tau о \varsigma$.

First-fruits shall be offered to the two goddesses, in accordance with ancestral custom

5 and the oracular response from Delphi, by the Athenians (as follows): from each one hundred medimnoi of

barley not less than one-sixth (of one medimnos); of wheat, from each hundred medimnoi,

not less than one-twelfth. If anyone produces more grain than [this amount] or less, he shall offer First-fruits in the same proportion. Collection shall be made by [the] Demarches deme by deme and they shall deliver it to the Hieropoio

10 from Eleusis at Eleusis. (The Athenians) shall construct three (storage) pits at Eleusis in accordance with the ancestral custom, at whatever place seems to the Hieropoioi and the

architect to be suitable, out of the funds of the two goddesses. The grain shall be put in there which they receive from the Demarches.

The allies as well shall offer first fruits according to the same procedure. The cities shall

15 have collectors chosen for the grain by whatever means seems best to them for grain collection. When it has been collected, they shall send it to Athens, and those who have brought it shall deliver it to the Hieropoioi from Eleusis at Eleusis. If (the latter) do not take delivery of it within five days after it has been reported to them, although it was offered by (the envoys) of whatever city [was the source]

20 of the grain, the Hieropoioi at their euthynai shall be fined one thousand drachmas [each].

$I G \mathrm{I}^{3} 78$; translation by ForNara 1983, 161, no 140.

$I G \mathrm{I}^{3} 78$ orders the delivery of $1 / 600$ th of the annual production of barley and $1 / 1,200$ th of the annual production of wheat to Eleusis. Moreno has suggested that the grain production

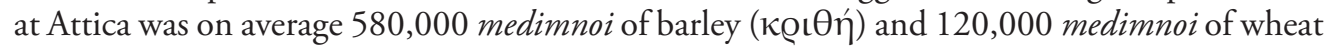
( $\pi$ UQós) a year. ${ }^{151}$ If we take 580,000 medimnoi of barley and 120,000 medimnoi as basis for the calculation of aparche, Athens had to deliver 966 medimnoi of barley and 100 medimnoi of wheat to Eleusis. The price for one medimnos of barley was ca 3 drachmas $\left(I G \mathrm{II}^{3} 360\right.$, line 9; $I G \mathrm{II}^{3} 1367$, line 10) and ca 6 drachmas for one medimnos of wheat $\left(I G \mathrm{II}^{2} 1356\right.$, lines 2 , $21)$ in the $4^{\text {th }}$ century BCE Athens. The aparche from Athens had a value of 3,398 drachmas (Table 4). The Delian League had at least 330 member city states. ${ }^{152}$ As not all cities were able to produce the same amount of barley and wheat as Athens, the member cities of the Delian 
League delivered different amount of barley and wheat as aparche to Eleusis. If we assume that 50 member city states were able to deliver as much as Athens, the aparche brought 48,300 medimnoi of barley and 5,000 medimnoi of wheat. Athens had to import wheat from other cities, as it was not able to produce enough wheat for its own population. According to Moreno, Athens imported approximately 1,300,000 medimnoi of wheat. ${ }^{153}$ The aparche ordered in $I G \mathrm{I}^{3}$ 78 brought probably less than 1,300,000 medimnoi of wheat. The aparche had to be sold and used for sacrifices performed in honour of Demeter and Persephone, dedications, and stelai $\left(I G \mathrm{I}^{3} 78\right.$, lines 36-44). The income from aparche ordered in $I G \mathrm{I}^{3} 78$ was considerable for the sanctuary of Demeter at Eleusis. If 50 cities delivered the same amount of aparche as Athens, Eleusis received approximately 179,000 drachmas as income from aparche (see Table 4).

Table 4. Athenian decree regulating the First-fruit payment to Eleusis: $I G \mathrm{I}^{3} 78$ (425 BCE) and $I G \mathrm{II}^{2} 1672(329$ $\mathrm{BCE}$ ). The following calculation is hypothetical.

\section{The member cities of the Delian League should pay}

$1 / 600$ th of the annual production of barley $\left(I G \mathrm{I}^{3} 78\right.$, line 6$)$

$1 / 1,200$ th of the annual production of wheat $\left(I G \mathrm{I}^{3} 78\right.$, line 7)

\section{The price of wheat and barley in the $4^{\text {th }}$ century BCE}

1 medimnos of wheat $=5$ drachmas $\left(I G \mathrm{II}^{3} 360\right.$, line 9; $I G \mathrm{II}^{3} 1367$, line 10); 6 drachmas $\left(I G \mathrm{II}^{2} 1356\right.$, lines 2, 21; $I G I^{2} 1672$, line 287); 9 drachmas for one medimnos of Sicilian wheat (IG $I^{3} 1339$, lines 12-13) 1 medimnos of barley $=3$ drachmas $\left(I G I^{2} 1672\right.$, lines 282-283); 5 drachmas $\left(I G I^{3} 1339\right.$, lines 13-14)

Aparche paid by Athens (for wheat and barley production at Attica, see Moreno 2007: 10, fig. 1) $1 / 600$ th of 580,000 medimnoi of barley $=966$ medimnoi (ca 31 tons)* $\rightarrow 2,898$ drachmas** $1 / 1,200$ th of 120,000 medimnoi of wheat $=100$ medimnoi $(\mathrm{ca} 2.5 \text { tons })^{*}$

$\rightarrow 500$ drachmas**

3,398 drachmas

Supposing 50 member city states of the Delian League also paid 966 medimnoi of barley and 100 medimnoi of wheat as aparche to Eleusis

966 medimnoi of barley x $50=48,300$ medimnoi (ca 1,497 tons)*

100 medimnoi of wheat $x 50=5,000$ medimnoi (ca 200 tons)*

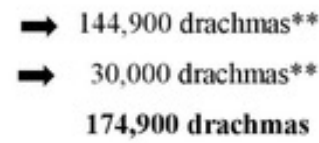

* medimnos of wheat was ca $40 \mathrm{~kg}$ and one medimnos of barley was ca $31 \mathrm{~kg}$

** medimnoi of barley multiplied by 3 , and medimnoi of wheat multiplied by 6

153 Moreno 2007, 10, table 1.

$154 I G \mathrm{II}^{3} 1339$ (lines 12-13); 9 drachmas for one medimnos of Sicilian wheat.

155 IG II $\mathrm{II}^{3} 1339$ (lines 13-14): one medimnos of barley for 5 drachmas. 
The decree $I G \mathrm{I}^{3} 32$ (lines 7-12) dating to 432/1 BCE regulates the selection of epistatai who were in charge of the administration of the finances of the sanctuary of Demeter and Persephone at Eleusis. ${ }^{156}$ The decree orders the selection of six Athenian men as epistatai (lines 7-8). This decree was released a few years before $I G \mathrm{I}^{3} 78$ and after $I G \mathrm{I}^{3} 6$. The high number of epistatai suggests that the income of the sanctuary of Demeter and Persephone at Eleusis was considerable. The income from aparche ordered a few years after this decree also required several officials in charge of the administration of the finances. Commercialized aparche and salvation (mysteries) were especially beneficial for the sanctuaries and cultic officials. The maintenance of the sanctuary, the construction of new buildings, and well-organised costly festivals also increased the significance of the sanctuary and the status of cultic officials.

Isocrates says that most Greek cities paid the aparche according to the ancestral customs (Paneg. 31). ${ }^{157}$ If we believe Isocrates, the Pythian priestess ordered the payment and admonished the cities, which neglected the payment. Many Greek cities agreed to pay, but not all cities (Paneg. 31). Clinton states that the sanctuary was embarking on a new era of prosperity at the time when Panegyricus was published, and a few cities were contributing the aparche. ${ }^{158}$ Isocrates as an Athenian rhetorician wrote from the perspective of Athens and emphasizes the leadership of Athens. It was important to highlight that many cities contributed the aparche and to encourage other cities to pay as well.

For most of the Hellenistic cities, in memory of our ancient services, send us each year the First-fruits of the harvest, and those who neglected to do so have often been admonished by the Pythian priestess to pay us our due portion of their crops and to observe in relation to our city the customs of their fathers. And about what, I should like to know, can we more surely exercise our faith than about matters as to which the oracle of Apollo speaks with authority, many of the Hellenes are agreed, and the words spoken long ago confirm the practice of today...

Isocrates, Panagyricus 31; translation by Norlin 1980.

$I G \mathrm{II}^{2} 1672$ mentions that different demes of Attica (lines 262-273), ${ }^{159}$ Skyros (lines 274275), Lemnos (lines 276-279), ${ }^{160}$ and Imbros (lines 298-302) paid the aparche to Eleusis. IG $\mathrm{II}^{2} 1672$ lists a few demes of Attica and islands depending on Athens, which paid the aparche to Eleusis in 329 BCE. Presumably, the allies of the Delian League paid the aparche to Eleusis as long as Athens had the political power to impose these payments.

$I G \mathrm{II}^{2} 1672$ refers to the financial account of the sanctuary of Demeter at Eleusis for the year 329/8 BCE and lists wages paid for various types of work. The cost listed for the annual maintenance of the sanctuary of Demeter and Persephone at Eleusis was approximately 40,000 drachmas. This sum includes wages, cost for buildings, food, etc. We learn from this inscription that the heralds who announced the Eleusinian Mysteries on islands received 240 drachmas ( $I G \mathrm{II}^{2} 1672$, line 4). The cost for the construction of a wall was 2,631 drachmas and

156 For the epistatai of the sanctuary of Demeter and Kore at Eleusis, see also $I G \mathrm{I}^{3} 386$.

157 Isocrates' Panegyricus was published around 380 BCE.

158 Clinton 2010, 1-2.

159 The following deme of Attica are listed in $I G \mathrm{II}^{2}$ 1672: Erechtheis, Aigeis, Pandionis, Leontis, Acamantis, Oineis,

Kekropis, Hippothontis, Aiantis, Antiochis, Drymos, Amphiaraos, and Salamin.

$160 I G \mathrm{II}^{2}$ 1672, lines 276-279, mentions Myrina and Hephaistia which were cities of Lemnos. 
3 obols ( $I G \mathrm{II}^{2}$ 1672, lines 25-26). The lines 300-301 mention that the money was retrieved from the thesauroi of the 'older' ( $\pi \varrho \varepsilon \sigma \beta u \tau \varepsilon \dot{\varrho} \alpha \varsigma)$ and 'young' ( $\varepsilon \varepsilon \omega \tau \dot{\varepsilon} \varrho \alpha \varsigma)$ goddesses who are referred to as Demeter and Persephone. Both goddesses had apparently two separate thesauroi. Depending on the ritual performed in honour of Demeter or Persephone, the fees were conveyed to the thesaurus of the respective goddess. It is, however, not sure whether the term 'thesaurus' refers to a treasury house or to a stone box. In the next lines, it is indicated that a man named Lykes was paid 4 drachmas to open the thesauroi $\left(I G \mathrm{II}^{2} 1672\right.$, lines 303-304). Iscr. di Cos ED 89 (line 23-24) also mentions that somebody was paid to open the thesaurus. The thesauroi mentioned in $I G \mathrm{II}^{2} 1672$ refer presumably to stone boxes. The sum of 4 drachmas paid for the opening of the thesauroi was the wages of skilled workers. Apparently, the thesauroi were locked with sophisticated lockers and were opened by skilled workers. Sophisticated lockers were important in order to protect the money deposited into the thesauroi. IG $\mathrm{II}^{2} 1672$ (lines 300-301) mentions an amount of money retrieved from two thesauroi. The sum was not significantly high: 500 drachmas, 5 obols, and 4 gold from the thesaurus of Demeter; 1,092 drachmas, 4 obols, and 1 gold from the thesaurus of Persephone. The two thesauroi mentioned in $I G \mathrm{II}^{2} 1672$ had probably the same size as the thesaurus dedicated to Theagenes that offers a space for approximately the same amount of coins retrieved from each of the thesauroi at Eleusis.

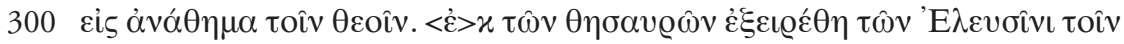

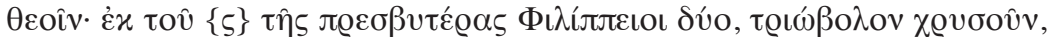

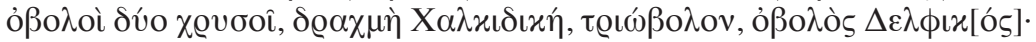

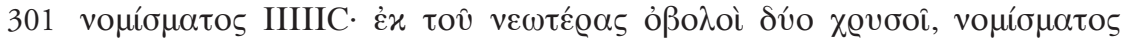

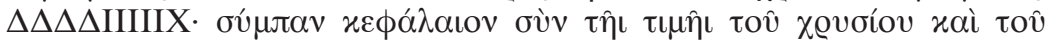

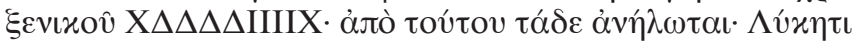

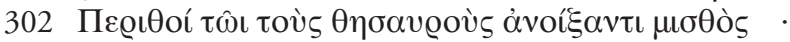

$I G \mathrm{II}^{2} 1672$

300 From the treasures of the Goddesses in Eleusis have been retrieved: the treasure of the older (goddess), 2 coins of Philip, 1 triobolon in gold, 2 obols in gold, 1 drachma from Chalcidice, 1 triobolon, 1 obol from Delphi,

301 a sum of money of 500 drachmas, 5 obols, 4 gold. From the treasure of the younger (goddess), 2 obols in gold, a sum of money of 540 drachmas, 5 obols, 5 gold. Total, with gold and foreign currencies $=1092$ drachmas, 4 obols, 1 gold. Spent from this sum: for Lykes

302 from Perithos, who opened the thesauroi, 4 drachmas

Each of the 2,000 or 3,000 initiates had to sacrifice a piglet at the Eleusinian Mysteries; this means 2,000-3,000 piglets. We do not know whether the initiates had to give one part of the meat as priestly share or money. Independently from the priestly share, the sanctuary had to organize the slaughtering en masse and cooking facilities, as the meat had to be cooked the same day and consumed within two days. As mentioned, animal sacrifice and priestly share were partially replaced by coins. Such regulation may also have been applied at Eleusis; however, there is no epigraphic evidence for it. It was useful for the sanctuary to have money than a surplus of meat. The fee asked for small animals on Cos was a half obol ( $H G K$ 17, lines 10-12) or 3 obols (SEG 50:766, lines 10-13; Iscr. di Cos ED 89, lines 18-24). Supposing that 
3 obols were also asked as a preliminary offering at piglet sacrifices performed by initiates at the Eleusinian Mysteries. By paying 3 obols for each piglet sacrifice, 2,000-3,000 piglet sacrifices brought 1,000-1,500 drachmas. The sum retrieved from the two thesauroi mentioned in $I G$ II $^{2} 1672$ (lines 300-301) corresponds to this amount. Therefore, we do not know whether these two thesauroi were exclusively used for fees asked at the Eleusinian Mysteries. The fees of 15 drachmas paid for the initiation into the Eleusinian Mysteries were collected by cultic officials and deposited into a building at Eleusis or Athens, as the thesauroi did not offer enough space for such a high sum (see Table 3).

Socrates says in a discussion recorded in Plato's Euthyphro 14c that sacrificing is making gifts to gods. Aristophanes' Plutos 1111-1115 also mentions that animal sacrifice, the offering of cakes, laurels, and incenses were gifts to deities. These gifts were crucial for the link between the worshippers and the deities. The offering of First-fruits was also a gift to the gods but was partially replaced by money. Animal sacrifice was an expensive matter, especially if cattle were sacrificed. IG $\mathrm{II}^{2} 1635$ (lines 35-37) dating to $374 \mathrm{BCE}$ mentions that 109 oxen were purchased for 8,419 drachmas. $I G \mathrm{I}^{3} 258$ (lines 4-10) dating to 420 BCE lists festival expenditures: 7,000 drachmas for the sanctuary of Heracles, 1,200 drachmas from Aphrodisia, 1,200 drachmas from Anakia, and 1,100 drachmas from Apollonia. These two inscriptions illustrate that a high amount of money was needed for festivals and animal sacrifices. However, such a high number of animals were not sacrificed at each festival and not for all deities. We should also distinguish between sacrifices performed at festivals celebrated by the whole community and sacrifices performed by single worshippers. Animal sacrifices performed by priests at festivals organised by the polis were crucial, as such rituals evoked in people a sense of commonality and enforced the bond between the community, sanctuary, and the polis. In everyday life, single offerings and animal sacrifices could be replaced by money, as the psychological impact is different. The value of an offering made by single worshippers is also determined by its monetary value. The worshipper could buy a sacrificial animal or give its monetary equivalent to the priest.

\section{Conclusion}

In the $7^{\text {th }}$ and $6^{\text {th }}$ centuries BCE, ingots were used as pre-monetary means of payment of fees and consecrated as votives. Only one part of ingots consecrated over a period was deposited as votives at a few sanctuaries of Demeter on Sicily. Coins replaced ingots in the $5^{\text {th }}$ century BCE. Ingots and coins are mainly attested for Doric cities, and especially for Western Greece. Coins as means of payment were beneficial for the sanctuaries and cultic officials, as money can be accumulated. The mercantile thinking and the monetarization of the markets have also influenced the offering practice and fees asked for various cultic services at the sanctuaries of Demeter. Coins consecrated at sanctuaries were conveyed to thesauroi and collected by cultic officials. One part of the coins consecrated between the $5^{\text {th }}$ and $2^{\text {nd }}$ centuries BCE was deposited in some sanctuaries of Demeter as votives or as treasuries.

Coins found at the sanctuaries of Demeter were made from gold, silver, bronze, and copper. Most coins found at different sanctuaries of Demeter were bronze coins, which were low-value coins. A small part of bronze coins consecrated by worshippers was deposited as votives. This is not only typical for the sanctuaries of Demeter but also for other sites. It is also interesting that most bronze coins found at the sanctuaries of Demeter were from different 
cities. Low- value bronze coins from other cities, which were not used as legal tender, seem more likely to be deposited as votives in sanctuaries.

A high number of coins in silver and gold were deposited as treasuries in the sanctuaries of Demeter at Gela, Morgantina, Kaunos, and Myrmekion. Some sanctuaries served as banks, where money and precious metal were deposited. Precious metals and coins were not only deposited as circulating capital but also as reserves of the sanctuaries. Such reserves were accumulated over centuries and deposited into pits or embodied into a wall, like at the sanctuary of Demeter in Myrmekion. For different reasons, some of these treasuries were not retrieved.

Thesauroi used as collection boxes for fees paid at various rituals are only attested by epigraphic and archaeological sources for a few sanctuaries of Demeter. The absence of thesauroi at most sanctuaries of Demeter does not necessarily provide evidence to indicate that thesauroi were not in use. Thesauroi were probably removed or destroyed when they were not in use anymore. Collecting fees in thesauroi was apparently a practice that existed during the Classical and Hellenistic periods. In later periods, the fees paid for various rituals were collected by cultic officials. In earlier periods too, money was not only conveyed to thesauroi, but also collected by cultic officials. The thesauro $i$ were opened once or twice a year and the income was used for the running cost of the sanctuary and as priestly share.

The epigraphic material from the Classical period offers testimony of the increased popularity of the Eleusinian Mysteries and the cult of Demeter promoted under the Athenian leadership to a Pan-Hellenic cult. The $5^{\text {th }}$ century BCE is also marked by the increased use of money as a means of payment. $I G \mathrm{I}^{3} 78$ ordered the sale of the grain delivered as aparche to Eleusis. This is interesting in many respects as the aparche was offered as thanksgiving to a deity. Selling the aparche means that an important offering was not made to the goddess. A certain amount of grain and sacrificial animals have a certain monetary value. The monetary value determined the value of offerings, animal sacrifices, and priestly share. The gods did not only enjoy the smell of burnt animals or offering of aparche, but also their monetary equivalent. Therefore, not all offerings were replaced by money. Animal sacrifices and First-fruit offering were important for several festivals and rituals, especially for those performed by the whole community. At collective rituals, the performance of each ritual was significant for the cult.

Aynur-Michèle-Sara Karatas

University of Bristol

17 Lansdown Road, Saltford,

BS31 3BB Bristol (UK) aramsk@my.bristol.ac.uk 
Bresson 2016

A. Bresson, The Making of the Ancient Greek Economy: Institutions, Markets, and Growth in the City-States, Princeton 2016.

Bruit ZaIDMAN 2007

L. Bruit Zaidman, "Le religieux et le politique : Déméter et Koré dans la cité athénienne ", in P. Schmitt, P. de Polignac (eds.) Athènes et le politique : Dans le sillage de Claude Mossé, Paris 2007, 57-82.

Bulba 2008

M. Bulba, "Demeterkult in Kaunos», in M. Novotná (ed.) Cult and Sanctuary through the Ages: From the Bronze Age to the Late Antiquity, Trnava 2008, 109-114.

Bulba 2010

M. Bulba, "Bothroi in Küçükkale in Kaunos», Belleten 271 (2010), 649-657.

ButCher 2016

K. Butcher, "Coin Finds and the Monetary Economy: The Good, the Bad, and the Irrelevant», in F. Duyrat, C. Grandjean (eds.) Les monnaies de fouille du monde grec (Vie - Ier s.a.C.): Apports, approches et méthodes, Bordeaux 2016, 225-237.

Buttrey, Erim, Groves, Holloway 1989

T.V. Buttrey, K.T. Erim, T.D. Groves, R.R. Holloway, Morgantina Studies II: The Coins, Princeton 1989.

Butyagin, Chistov 2006

A.M. Butyagin, D.E. Chistov, "The Hoard of Cyzicenes and Shrine of Demeter at Myrmekion", Ancient Civilisations from Scythia to Siberia 12 (2006), 77-131.

Butyagin, Treister 2006

A.M. Butyagin, M.Y. Treister, 2006. A Bronze Olpe from the Myrmekion Hoard, Ancient Civilisations from Scythia to Siberia 12, 133-146.

Cavanagh 1996

M.B. Cavanagh, Eleusis and Athens: Documents in Finances, Religion and Politics in the Fifth Century B.C., Atlanta 1996.

\section{ÇIZMeli-Ögün, Marcellesi 2011}

Z. Çizmeli-Ögün, M.C. Marcellesi, "Réseau d'échanges régionaux en Asie Mineure occidentale : des monnaies de fouilles ", in T. Faucher, M.-C. Marcellesi, O. Picard (eds.) Nomisma. La circulation monétaire dans le monde grec antique (Actes du colloque international, Athènes 14-17 avril 2010), Athens 2011, 297-342.

\section{Clinton 1974}

K. Clinton, The Sacred Officials of the Eleusinian Mysteries, Philadelphia 1974.

\section{Clinton 1988}

K. Clinton, «Sacrifice at the Eleusinian Mysteries», in R. Hägg, N. Marinatos, G.C. Nordquist (eds.) Early Greek Cult Practice, Stockholm 1988, 69-80.

\section{Clinton 2010}

K. Clinton, "The Eleusinian Aparche in Practice: 329/8 B.C.», in I. Leventi, C. Mitsopoulou (eds.) Sanctuaries and Cults of Demeter in the Ancient Greek World, Volos 2010, 1-15.

\section{Coldstream 1973}

J.N. Coldstream, "The Jewellery and other Small Finds», in J.N. Coldstream (ed.) Knossos: The Sanctuary of Demeter, Oxford 1973, 130-176.

DAVIES 2001

J.K. Davies, Temples, Credit, and the Circulation of Money, in A. Meadows, K. Shipton (eds.) Money and its Uses in the Ancient Greek World, Oxford 2001, 117-144

De Angelis 2016

F. De Angelis, Archaic and Classical Greek Sicily: A Social and Economic History, Oxford 2016.

Descat 1997

R. Descat, "La géographie dans les listes des tributs attique : Lepsimandos et Kasôlaba en Carie ", Zeitschrift für Papyrologie und Epigraphik 104 (1997), 61-68.

DeVelin 1989

R. Develin, Athenian Officials 684-321 BC, Cambridge 1989. 
Dignas 2004

B. Dignas, Economy of the Sacred in Hellenistic and Roman Asia Minor, Oxford 2004.

ELLIS-Evans 2013

A. Ellis-Evans, "The Ideology of Public Subscription", in P. Martzavou, N. Papazarkadas (eds.) Epigraphical Approaches to the Post-Classical Polis: Fourth Century BC to Second Century $A D$, Oxford 2013, 107-121.

\section{FigueIRA 1998}

T. Figueira, The Power of Money: Coinage and Politics in the Athenian Empire, Philadelphia 1998.

Fiorentini 1969

G. Fiorentini, «Il santuario extraurbano di S. Anna presso Agrigento", Cronache Arch. 8 (1969), 63-80.

FORNARA 1983

C.W. Fornara, Archaic Times to the End of the Peloponnesian War, Cambridge 1983.

Frey-Kupper 2016

S. Frey-Kupper, «Le monete antiche», in: F. Spatafora (ed.) Il Thesmophorion di Entella, Pisa 2016, 285-293.

Gatzolis 2011

C. Gatzolis, «Royal and Civic Bronze Coinage: Monetary Circulation Between the Macedonian Kingdom and the Chalcidic Peninsula», in T. Faucher, M.-C. Marcellesi, O. Picard (eds.) Nomisma. La circulation monétaire dans le monde grec antique (Actes du colloque international, Athènes 14-17 avril 2010), Athens 2011, 185-198.

Gatzolis, Psoma 2016

C.A. Gatzolis, S.E. Psoma, "Olynthos and Stageira: Bronze Coinage and Political History», in F. Duyrat, C. Grandjean (eds.) Les monnaies de fouille du monde grec (Vie - Ier s.a.C.): Apports, approches et méthodes, Bordeaux 2016, 83-96.

Grandjean 2016

C. Grandjean, Les monnaies grecques des fouilles de l'École française d'Athènes à Argos, in F. Duyrat, C. Grandjean (eds.) Les monnaies de fouille du monde grec (Vie - Ier s.a.C.): Ap- ports, approches et méthodes, Bordeaux 2016, 51-63.

Gygax 2016

M.D. Gygax, Benefaction and Rewards in the Ancient Greek City: The Origins of Euergetism, Cambridge 2016.

Herzog 1901

R. Herzog, «Bericht über eine epigraphischarchäologische Expedition auf der Insel Kos im Sommer 1900", AA 16 (1901), 131-140.

Hinz 1998

V. Hinz, Der Kult von Demeter und Kore auf Sizilien und in der Magna Graecia, Wiesbaden 1998.

IşıK 2000

C. Işık, «Demeter in Kaunos», BCH Supplément (2000), 229-240

IșıK 2010

C. Işık, «Kaunos'un bereket tanrıçası Demeter'in izinde», Bütün Dünya Şubat (2010), 88-96

JACKSON 1973

A. Jackson, «The Coins», in J.N. Coldstream (ed.) Knossos: The Sanctuary of Demeter, Oxford 1973, 99-107.

JIM 2014

T.S.F. Jim, Sharing with the Gods: Aparchai and Dekatai in Ancient Greece, Oxford 2014.

Kabus-Preisshofen 1975

R. Kabus-Preisshofen, «Statuettengruppe aus dem Demeterheiligtum bei Kyparissi auf Kos", AntPlXV (1975), 31-64.

KAMINSKI 1991

G. Kaminski, «Thesaurus. Untersuchungen zum antiken Opferstock», JDAI 106 (1991), 63-181.

\section{KANTZIA 1988}

C. Kantzia, «Recent Archaeological Finds from Kos: New Indications for the Site of Kos-Meropis», in S. Dietz, I. Papachristodoulou (eds.) Archaeology in the Dodecanese, Copenhagen 1988, 175-183.

Karatas 2015

A.M.S. Karatas, The Sanctuaries of Demeter in 
Western Asia Minor and on the Islands off the Coast, Dissertation, University of Bristol 2015.

KonUK 2007

K. Konuk, "Coin Legends in Caria", in I.J. Adiego (ed.) The Carian Language, Leiden 2007, 471-492.

\section{KRON 1992}

U. Kron, «Frauenfeste in Demeterheiligtümern: das Thesmophorion von Bitalemi», $A A$ (1992), 611-650.

\section{LATACZ 1990}

J. Latacz, «Die Funktion des Symposions für die entstehende griechische Literatur», in W. Kullmann, M. Reichel (eds.) Der Übergang von der Mündlichkeit zur Literatur bei den Griechen, Tübingen 1990, 227-264.

LAU 1924

B. Lau, Heiliges Geld: Eine historische Untersuchung über den sakralen Ursprung des Geldes, Tübingen 1924

\section{LEWIS 1968}

D.M. Lewis, «New Evidence for the Gold-Silver Ratio", in C.M. Kray, G.K. Jenkins (eds.) Essays in Greek Coinage, Presented to Stanley Robinson, Oxford 1968, 105-110.

\section{MARTIN 1940}

R.R. Martin, «Un nouveau règlement de culte thasien ", BCH 64-65 (1940), 163-300.

Meyer 1987

M.W. Meyer, The Ancient Mysteries: A Sourcebook, Philadelphia 1987.

Migeotte 1992

L. Migeotte, Les souscriptions publiques dans les cités grecques, Québec 1992.

\section{Migeotte 1998}

L. Migeotte, "Cinq souscriptions féminines à Cos à la période hellénistique ", Revue des Études Anciennes 100 (1998), 565-578.

\section{Moreno 2007}

A. Moreno, Feeding the Democracy: The Athenian Grain Supply in the Fifth and Fourth Centuries $B C$, Oxford 2007.

Murray 1985

W.M. Murray, «The Weight of Trireme Rams and the Price of Bronze in Fourth-Century Athens", Greek, Roman, and Byzantine Studies 26.2 (1985), 141-150.

NoEgel 2007

S.B. Noegel, "Greek Religion and the Ancient Near East», in D. Ogden (ed.) A Companion to Greek Religion, Oxford 2007, 21-37.

NORLIN 1980

G. Norlin, Isocrates, London 1980.

OHLERICH 2009

I. Ohlerich, Kultorte und Heiligtümer auf dem Gebiet des Bosporanischen Reiches Vom Beginn der Kolonisation bis zum Ende des 2. Jh. v. Chr., Dissertation, University of Rostock 2009.

OrLandini 1965

P. Orlandini, «Gela - Depositi votivi di bronzo premonetale nel santuario di Demetra Thesmophoros a Bitalemi», Annali. Istituto italiano di numismatica 1214 (1965), 1-20

OrLandini 1966

P. Orlandini, «Lo scavo del thesmophorion di Bitalemi e il culto delle divinità ctonie a Gela», Kokalos 12 (1966), 8-39.

OrLandini 2008

P. Orlandini, «Demetra a Gela», in C.A. di Stefano (ed.) Demetra, la divinità, $i$ santuari, il culto, la leggenda, Pisa; Roma 2008, 173-186.

PAfFord 2006

I.A. Pafford, Cult Fees and the Ritual of Money in Greek Sanctuaries of the Classical and Hellenistic Periods, Dissertation, University of California, Berkeley 2006.

PAFFORD 2013

I.A. Pafford, «Priestly Portion v. Cult Fee: The Finances of Greek Sanctuaries», in M. Horster, A. Klöckner (eds.) Cities and Priests: Cult Personnel in Asia Minor and the Aegean Islands from the Hellenistic to the Imperial Periods, Berlin 2013, 49-64.

Pazdera 2006

M. Pazdera, Getreide für Griechenland: Untersuchungen zu den Ursachen der Versorgungskrise im Zeitalter Alexander des Großen und der Diadochen, Berlin 2006. 
PicARd 1990

O. Picard, "Les oboles de Théogénès ", Mélanges Pierre Lévêque 5 (1990), 315-323.

PicARd 2016

O. Picard, « Les monnaies de fouilles du monde grec ", in F. Duyrat, C. Grandjean (eds.) Les monnaies de fouille du monde grec (Vie - Ier s.a.C.): Apports, approches et méthodes, Bordeaux 2016, 65-81.

Price 1968

M.J. Price, «Early Greek Bronze Coinage», in C.M. Kray, G.K. Jenkins (eds.) Essays in Greek Coinage Presented to Stanley Robinson, Oxford 1968, 90-104.

SCHUDDEBOOM 2009

F.L. Schuddeboom, Greek Religious Terminology - Telete \& Orgia: A Revised and Expanded English Edition of the Studies by Zijderveld and Van der Burg, Leiden 2009.

SEAFORD 2004

R. Seaford, Money and the Early Greek Mind: Homer, Philosophy, Tragedy, Cambridge 2004.

SisMANIDIs 1999

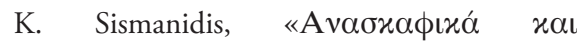

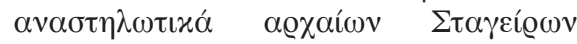
1997», AEM@ 11 (1999), 469-479.

SISMANIDIS 2003

K. Sismanidis, Ancient Stageira: Birthplace of Aristotle, Athens 2003.

SJöQvist 1960

E. Sjöqvist, «Morgantina: Hellenistic Medicine Bottle», AJA 64 (1960), 78-83.

SJÖQVIST 1964

E. Sjöqvist «Excavation at Morgantina (Serra Orlando) 1963, Preliminary Report VIII», AJA 68 (1964), 137-147.

SмIтн 1973

D.R. Smith, «The Hieropoioi on Kos», Numen 20 (1973), 38-47.

SoKolOwsKi 1954

F. Sokolowski, «Fees and Taxes in the Greek Cults», The Harvard Theological Review 47 (1954), 153-164.
SoKolowski 1959

F. Sokolowski, «On the Rules Regulating the Celebration of the Eleusinian Mysteries», The Harvard Theological Review 52 (1959), 1-7.

SoKoLOwsKI 1962

F. Sokolowski Lois sacrées des cités grecques, Supplément, Paris 1962.

Sposito 2008

A. Sposito, «Architettura e rito nel santuario della divinità ctonie a Morgantina», in C.A. di Stefano (ed.) Demetra: La divinità, i santuari, il culto, la leggenda, Pisa; Rome 2008, 221-234.

STANCOMB 2006

W.M. Stancomb, «A Hoard found at Myrmekion, North-East of Panticapaeum, Ukraine», The Numismatic Chronicle 166 (2006), 373374.

STILLWELL 1959

R. Stillwell, «Excavations at Serra Orlando 1958, Preliminary Report III», AJA 63 (1959), 167-173.

TARDITI 2016

C. Tarditi, «The Metal Objects from the Sanctuary of Bitalemi and their Context», in H. Baitinger (ed.) Materielle Kultur und Identität im Spannungsfeld zwischen mediterraner Welt und Mittelmeer, Mainz 2016, 49-68.

VERGER 2011

S. Verger, «Dévotions féminines et bronzes de l'extrême nord dans le thesmophorion de Géla ", in F. Quantin (ed.) Archéologie des religions antiques : contributions à l'étude des sanctuaires et de la piété en Méditerranée (Grèce, Italie, Sicile, Espagne), Pau 2011, 15-76.

White 1984

D. White, The Extramural Sanctuary of Demeter and Persephone at Cyrene, Libya: Final Reports IV, Philadelphia, [Pa.] 1984. 